\title{
Physical basis of coastal adaptation on tropical small islands
}

\author{
Donald L. Forbes • Thomas S. James • \\ Michael Sutherland $\cdot$ Susan E. Nichols
}

Received: 2 October 2012/ Accepted: 4 May 2013/Published online: 9 June 2013

(c) The Author(s) 2013. This article is published with open access at Springerlink.com

\begin{abstract}
Small tropical islands are widely recognized as having high exposure and vulnerability to climate change and other natural hazards. Ocean warming and acidification, changing storm patterns and intensity, and accelerated sea-level rise pose challenges that compound the intrinsic vulnerability of small, remote, island communities. Sustainable development requires robust guidance on the risks associated with natural hazards and climate change, including the potential for island coasts and reefs to keep
\end{abstract}

Handled by John E. Hay, Ibaraki University, Japan.

Portions of this paper were originally presented at the LOICZ Open Science Conference, Session A4, Yantai, China, September 2011.

D. L. Forbes $(\square)$

Natural Resources Canada, Geological Survey of Canada,

Dartmouth, NS B2Y 4A2, Canada

e-mail: dforbes@nrcan.gc.ca

D. L. Forbes

Department of Geography, Memorial University of

Newfoundland, St. John's, NL, Canada

T. S. James

Natural Resources Canada, Geological Survey of Canada,

Sidney, BC, Canada

T. S. James

School of Earth and Ocean Sciences, University of Victoria,

Victoria, BC, Canada

M. Sutherland

Geomatics Engineering and Land Management, University of the West Indies, St. Augustine, Trinidad and Tobago

M. Sutherland · S. E. Nichols

Geodesy and Geomatics Engineering, University of New

Brunswick, Fredericton, NB, Canada pace with rising sea levels. Here we review these issues with special attention to their implications for climatechange vulnerability, adaptation, and disaster risk reduction in various island settings. We present new projections for 2010-2100 local sea-level rise (SLR) at 18 island sites, incorporating crustal motion and gravitational fingerprinting, for a range of Intergovernmental Panel on Climate Change global projections and a semi-empirical model. Projected 90-year SLR for the upper limit A1FI scenario with enhanced glacier drawdown ranges from 0.56 to $1.01 \mathrm{~m}$ for islands with a measured range of vertical motion from -0.29 to $+0.10 \mathrm{~m}$. We classify tropical small islands into four broad groups comprising continental fragments, volcanic islands, near-atolls and atolls, and high carbonate islands including raised atolls. Because exposure to coastal forcing and hazards varies with island form, this provides a framework for consideration of vulnerability and adaptation strategies. Nevertheless, appropriate measures to adjust for climate change and to mitigate disaster risk depend on a place-based understanding of island landscapes and of processes operating in the coastal biophysical system of individual islands.

Keywords Volcanic island - Atoll - Reef island - Climate change $\cdot$ Sea-level rise $\cdot$ Disaster risk reduction

$\begin{array}{ll}\text { Abbreviations } \\ \text { AR4 } & \text { Fourth Assessment Report (IPCC) } \\ \text { ASL } & \text { Above sea level } \\ \text { ENSO } & \text { El Niño-southern oscillation } \\ \text { GMSL } & \text { Global mean sea level } \\ \text { GNSS } & \text { Global navigation satellite systems } \\ \text { GPS } & \text { Global positioning system } \\ \text { IGS } & \text { International GNSS Service } \\ \text { IPCC } & \text { Intergovernmental Panel on Climate Change }\end{array}$


MSL Mean sea level

NAO North Atlantic oscillation

SLR Sea-level rise

SRES Special report on emission scenarios (IPCC)

\section{Introduction}

The physical vulnerability of small island developing states, particularly with respect to accelerated sea-level rise (SLR), has been widely recognized as a major concern in the face of future climate change (Mimura et al. 2007; Barnett and Campbell 2010). Small islands within larger states face similar challenges (e.g., Schwerdtner Máñez et al. 2012), although internal assistance and migration options may be available to alleviate vulnerability. Despite many gaps in our knowledge of island shore-zone geomorphology and dynamics, there is a clear need for robust guidance on the risks associated with natural hazards and climate change and the potential for island coasts and reefs to keep pace with rising sea levels over coming decades. Here we review these issues with special attention to their geographic variability and the role they play in climate-change adaptation and disaster risk reduction. Our focus is on tropical and sub-tropical small islands in the Atlantic, Pacific, and Indian Oceans, broadly confined within the band of $\pm 40^{\circ}$ latitude (Fig. 1).

\section{Coastal vulnerability in small island developing states}

Physical exposure and accelerated environmental change account for only part of the vulnerability of small islands.
Challenges to sustainability can result from a broad spectrum of issues linked to demography and population density, health and well-being, culture and social cohesion, ecological integrity and subsistence resources, equity and access to capital, economic opportunity, basic services, technical capacity and critical infrastructure, among others. Many of the same issues apply to risk management and capacity for disaster risk reduction in small island states (Herrmann et al. 2004). Development pressures from these and other drivers compound the challenges of climatechange adaptation and risk reduction in small island states (Pelling and Uitto 2001). Efforts to enhance adaptive capacity and community resilience require a broad and holistic strategy and most likely a polycentric and multistakeholder approach (Ostrom 1999, 2010). Appropriate institutional, cultural, social, and policy mechanisms are required to support flexible and sustainable adaptation.

Within this framework, the geological, climatic, and oceanographic contexts are fundamental to the nature of exposure and key factors in managing adaptation to environmental change. Moreover, the impacts of climate change may first become apparent in major storms or other extreme events. Many years of development (sometimes with unrecognized maladaptation) may precede rare and catastrophic storms. The connection between extreme events and climate-change impacts points to the importance of physical vulnerability. Fundamental challenges in the management of coastal resources on many small islands include a scarcity of data and a lack of awareness of the natural processes and variability of coastal systems (Nunn et al. 1999; Lata and Nunn 2011). Realistic (data-backed) projections of future impacts (and associated uncertainties), greater understanding of coastal sediment dynamics, and

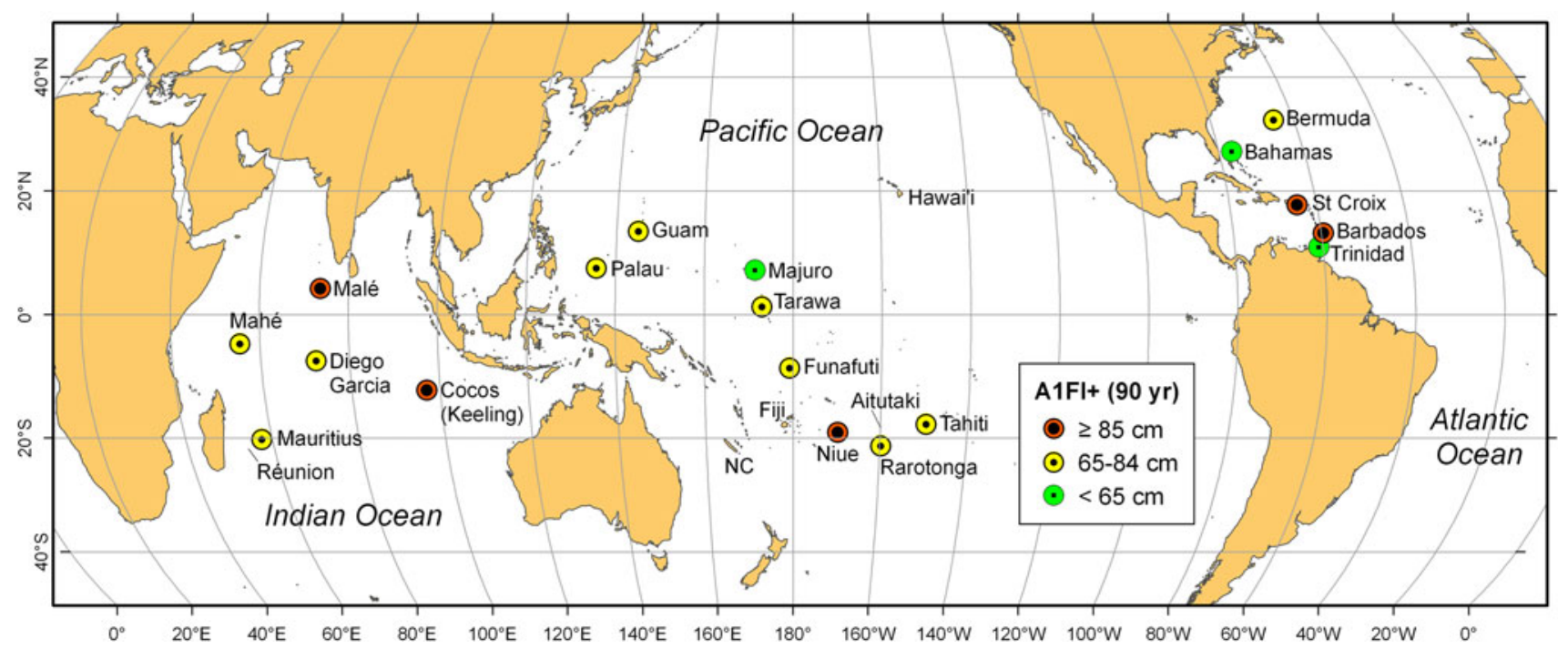

Fig. 1 Tropical and sub-tropical island belt, showing 90-year sea-level rise (SLR) projections (2010-2100) for a selection of islands under the $\mathrm{A} \mathrm{FI}_{\mathrm{MAX}}+$ scenario (see text and Table 1) 
strategies to enhance the natural function of reef and shorezone biophysical systems are key prerequisites for robust adaptation.

Many economic functions on small islands are dependent on coastal access and resources. Tourist infrastructure is targeted predominantly to coastal sites, where inappropriate siting, design or management can augment vulnerability (Shaw et al. 2005). Critical port facilities are necessarily located at the coast and much port, road, and other infrastructure is vulnerable to damage from local or far-travelled tsunami, storm waves, or exceptional tides on anomalously high sea levels (Solomon and Forbes 1999; Jackson et al. 2005; Fritz et al. 2011; Donner 2012). In atolls, limited freshwater lenses and saltwater intrusion or contamination by rising sea levels or storms constrain development and limit agricultural production (Mimura et al. 2007).

Tropical small islands are bolstered by protective biological resources. It is widely recognized that coral reefs are the world's largest coastal protection structures, but widespread degradation observed in many of the world's reef systems can been attributed to a combination of climate and human impacts (Carilli et al. 2010; Harris et al. 2010; Perry et al. 2013). The importance of reef systems for coastal stability, as both protective structures and sediment incubators, as well as the many other ecosystem services they provide, underlines the need to promote reef health (McClanahan et al. 2002).

Accelerated SLR is one of the most pressing concerns of island residents, particularly the inhabitants of low-lying atolls. Large proportions of habitation and infrastructure are usually concentrated near the coast, even on high-relief islands, and the effects of future SLR, including impacts on reef systems and shoreline stability, are important. Communities occupying low-elevation coastal terraces on high islands are exposed to tsunami runup, storm waves, marine and river flooding, and erosion, but remain in exposed locations for a variety of cultural or economic reasons. Nevertheless, some communities have relocated to higher ground in response to severe impacts from SLR and coastal storms in former shorefront locations (Nunn et al. 1999).

\section{Approach and methodology}

This paper is largely a review, intended to highlight the biophysical settings and associated physical vulnerabilities that need to be considered in adaptation and sustainable development strategies for tropical and sub-tropical island communities. We propose a geomorphic classification of island types as a framework for assessing relative exposure to a range of coastal hazards. An exhaustive review of island conditions is beyond the scope of the paper, but we draw examples from our experience on Indian, Pacific, and Atlantic oceanic islands and islands in the Caribbean.
We address the science and data constraints for developing robust, island-specific projections of sea-level change. SLR integrates the effects of two major contributions: (1) changing ocean density with warming of the surface mixed layer of the ocean, and (2) addition of water to the ocean basins by melting of land-based ice (Church and White 2006; Cazenave and Llovel 2010). The regional distribution of SLR is determined in part by gravitational effects involving the relative proportions of meltwater from various regions and distances to source, as well as by largescale ocean dynamics not considered here. Following Mitrovica et al. (2001) and James et al. (2011), we compute this so-called 'fingerprinting' component of future sealevel rise, which contributes to spatial variability. In general, for tropical islands remote from the poles, the fingerprinting may slightly enhance SLR. We then compute island-specific projections under various special report on emission scenarios (SRES) possible futures (Nakicenovic and Swart 2000; Nicholls et al. 2012) using projections of global mean SLR from the Fourth Assessment Report (AR4) of the Intergovernmental Panel on Climate Change (IPCC) (Meehl et al. 2007). We also consider an example of semi-empirical projections published since the AR4 (e.g., Rahmstorf 2007; Grinsted et al. 2009; Jevrejeva et al. 2010, 2012). We combine the resulting estimates with measurements of vertical land motion to estimate plausible ranges of future sea levels. We provide estimates for a representative set of 18 widely distributed island sites for which vertical motion is available. These computations are adjusted to 90 years to give the rise in mean sea level from 2010 to 2100.

Data on past sea levels are taken from the estimates of global mean sea level (GMSL) by Church et al. (2006) and more recently from satellite altimetry data, both of which are provided on-line by CSIRO (http://www.cmar.csiro.au/ sealevel/index.html). Monthly and annual mean sea levels for island stations are obtained from the Permanent Service for Mean Sea Level (PSMSL) (Woodworth and Player 2003; http://www.psmsl.org/data/obtaining/) and other sources in the Caribbean (Sutherland et al. 2008). Data on vertical land motion are derived from global satellite navigation system (GNSS) stations using on-line records and velocity estimates, primarily from the Jet Propulsion Laboratory (JPL) (http://sideshow.jpl.nasa.gov/post/series. html).

Estimates of wave runup are derived from field observations by the authors and published data. Field surveys of coastal berms or beach ridges in Mahé and Praslin (Seychelles), Viti Levu (Fiji), Tarawa (Kiribati), and Aitutaki (Cook Islands) by Jackson et al. (2005), Forbes et al. (1995), Forbes and Biribo (1996) and Forbes (1995) respectively, were undertaken using graduated rods and horizon (adaptation of Emery 1961) or electronic total 
station methods and referenced in most cases to the reef flat, representing a low-water datum, and to local survey control. Surveys in the Seychelles were tied to global positioning system (GPS) control and the mean sea level (MSL) datum using post-processed static differential surveys and tidal records (Jackson et al. 2005).

\section{Small island types and associated physical vulnerability}

Tropical and sub-tropical small islands can be classified into several broad categories on the basis of geology, bathymetry, topography, and geomorphic evolution (e.g., Scott and Rotondo 1983; Solomon and Forbes 1999; Nunn 1994; Woodroffe 2002). Here we consider tropical oceanic islands under four broad categories (Fig. 2).

- high volcanic islands (active or inactive), with fringing, emergent, or barrier reefs

- near-atolls and atolls

- emergent limestone islands including raised atolls

- continental fragments

\section{High volcanic islands}

Volcanic islands have rugged or mountainous interiors and a wide range of summit elevations, among the highest being Mauna Kea (Hawai'i) at 4,205 m. Many older and inactive volcanic islands are lower, reflecting long-term plate motion and subsidence (Scott and Rotondo 1983) and initially rapid

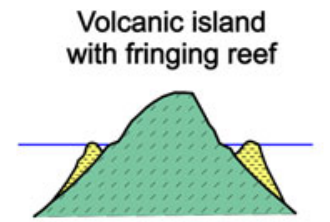

Subsided volcanic island with barrier reef (near-atoll)

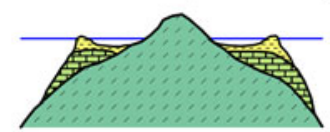

Emergent limestone island or raised atoll

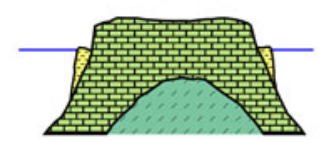

Holocene reef and sediments

Pleistocene reef limestone

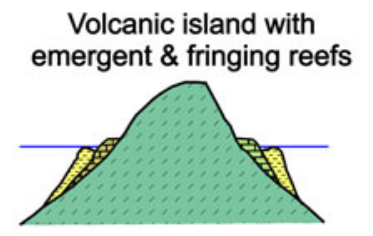

Atoll

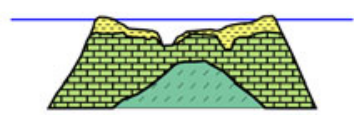

Continental fragment

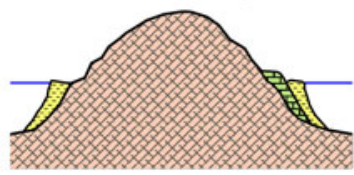

Volcanic edifice

Crystalline basement
Fig. 2 Major types of oceanic islands. Horizontal line is present-day sea level denudation (e.g., Louvat and Allègre 1997). Most oceanic volcanic islands rise from abyssal depths (e.g., Oehler et al. 2008). Rarotonga, with a peak elevation of $658 \mathrm{~m}$ above sea level (ASL), rises from an abyssal depth of about 4,000 m, where its diameter is $50 \mathrm{~km}$-five times that of the subaerial island (Fig. 3). Here, as on many high islands, there is a narrow coastal plain or terrace composed of sand and gravel derived from both the reef and slopes above, or in some cases consisting of elevated reef flat limestone or cemented conglomerate. Steep slopes and tropical forest cover limit the use of interior lands for settlement on many islands. As a result, community development, roads, and other infrastructure are concentrated largely along the coastal margin, increasing exposure to coastal hazards (Fig. 3).

High volcanic islands are often surrounded by protective fringing or barrier reefs, which may enclose lagoons of varying size (Darwin 1842; Nunn 1994). Reef health and productivity may be compromised in such settings by the steep slopes and thick soils of high island interiors, where extreme rainfall can trigger high runoff, landslides, and debris flows (e.g., Harp et al. 2004). Larger islands may also have major rivers, creating flood hazards and delivering large quantities of sediment, which can dominate coastal morphology in the vicinity of their outlets (e.g., Mimura and Nunn 1998; Kostaschuk et al. 2001).

Near-atolls, atolls, and reef islands

Atolls are more or less annular reef and reef-island systems found predominantly in oceanic mid-plate settings, where they rest on the peaks of submarine volcanic edifices

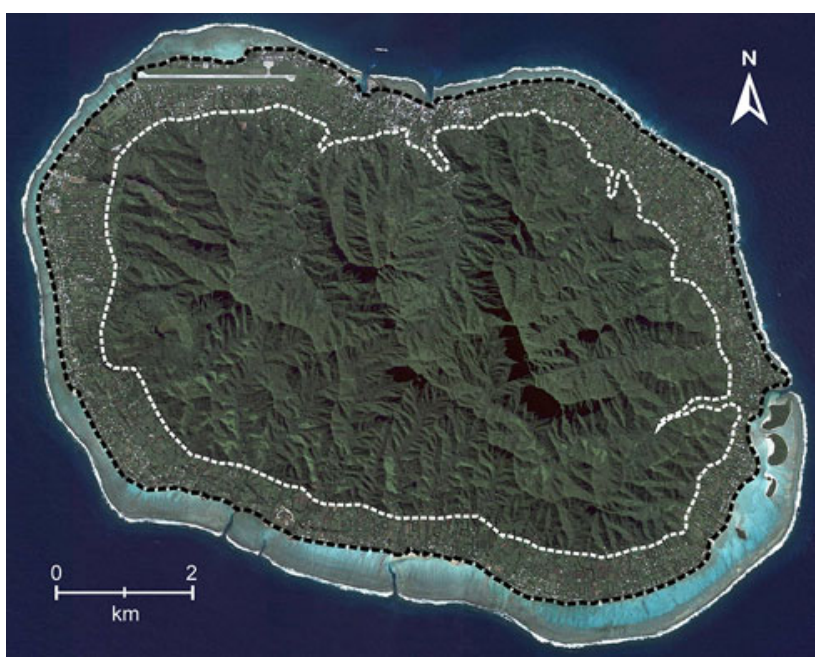

Fig. 3 Volcanic island of Rarotonga, Cook Islands, 24 June 2007. Image source: NASA (courtesy Wikimedia Commons, http://en. wikipedia.org/wiki/File:Rarotonga_Island.jpg). Black line Island shoreline. Note rugged interior (within white line), settlement concentrated on coastal terrace (between black and white lines), and fringing reef surrounding the island 
(Fig. 2). Darwin (1842) referred to barrier reefs surrounding volcanic islands as an intermediate stage in the development of atolls through long-term subsidence and reef growth. Others have referred to such 'near-atolls' as 'almost-atolls' (Stoddart 1975). Aitutaki in the southern Cook Islands is a good example (Fig. 4), with a $17 \mathrm{~km}^{2}$ central volcanic upland rising to $120 \mathrm{~m}$ ASL and two very small volcanic islands in the southeastern lagoon (Forbes 1995). The total area inside the surrounding reef is more than $70 \mathrm{~km}^{2}$ (by contrast Chuuk is more than $2,800 \mathrm{~km}^{2}$ ). Aitutaki is subject to moderately frequent storms (de Scally 2008), during which the reef takes the brunt of deepwater wave energy, but combined surge and setup with overtopping allows some wave energy to penetrate across the reef flat and lagoon to form a high berm on the western side of the island (Forbes 1995; Allen 1998).

Atolls lack an emergent volcanic core and are characterized by very low maximum elevations, limited land area, and thin freshwater lenses (McLean and Woodroffe 1994).
With long-term subsidence typical of many atolls (Scott and Rotondo 1983), the volcanic peak is submerged and capped by limestone (Fig. 2). With fluctuating sea levels over glacial-interglacial cycles, most present-day atolls have been exposed subaerially during glacial lowstands, experiencing solution and denudation (Woodroffe 2002). Reefs are reactivated when sea levels rise again. Depending on rates of SLR and coral productivity, reefs may keep up with sea level, fall behind (becoming submerged), or catch up (if the rate of SLR diminishes or productivity increases) (Neumann and Macintyre 1985). The vertical growth potential of corals and coralline algal reef builders depends on a number of factors, but rates as high as $8 \mathrm{~m} / \mathrm{ka}$ (metres per 1,000 years) have been reported from Mayotte Atoll in the Comoros, western Indian Ocean (Camoin et al. 1997) and 9-15 m/ka from the Caribbean (Adey 1978), although recent observations show a marked decline in some regions (e.g., Perry et al. 2013). The atolls and atoll reef islands observed today are geologically young features, having
Fig. 4 Near-atoll of Aitutaki, southern Cook Islands, showing central volcanic core and two small volcanic outliers, surrounded by a barrier reef and lagoon with partial rim of reef islands (from Forbes 1995). Broken line Reef. Reproduced with permission from the Secretariat of the Pacific Community, New Caledonia

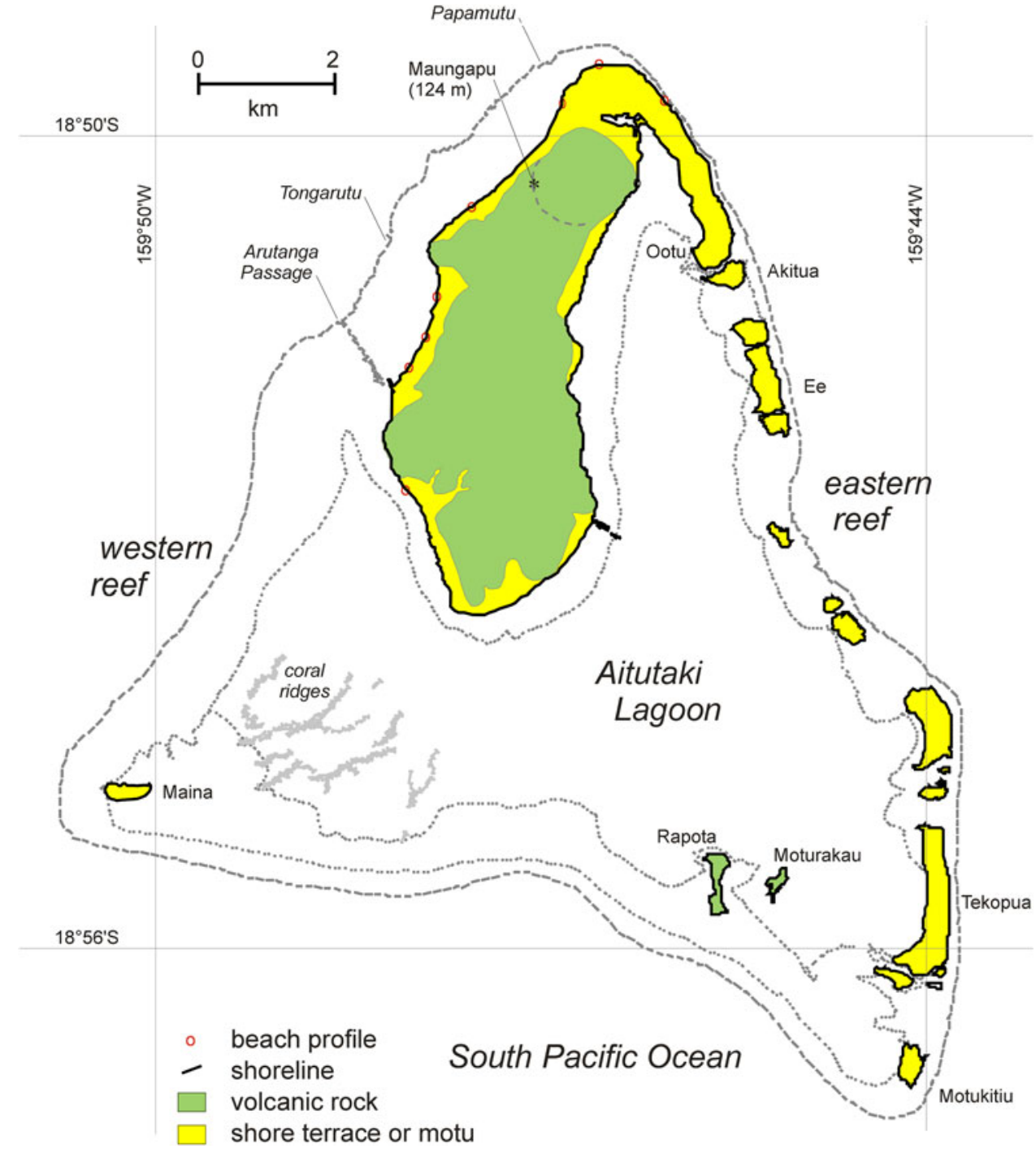



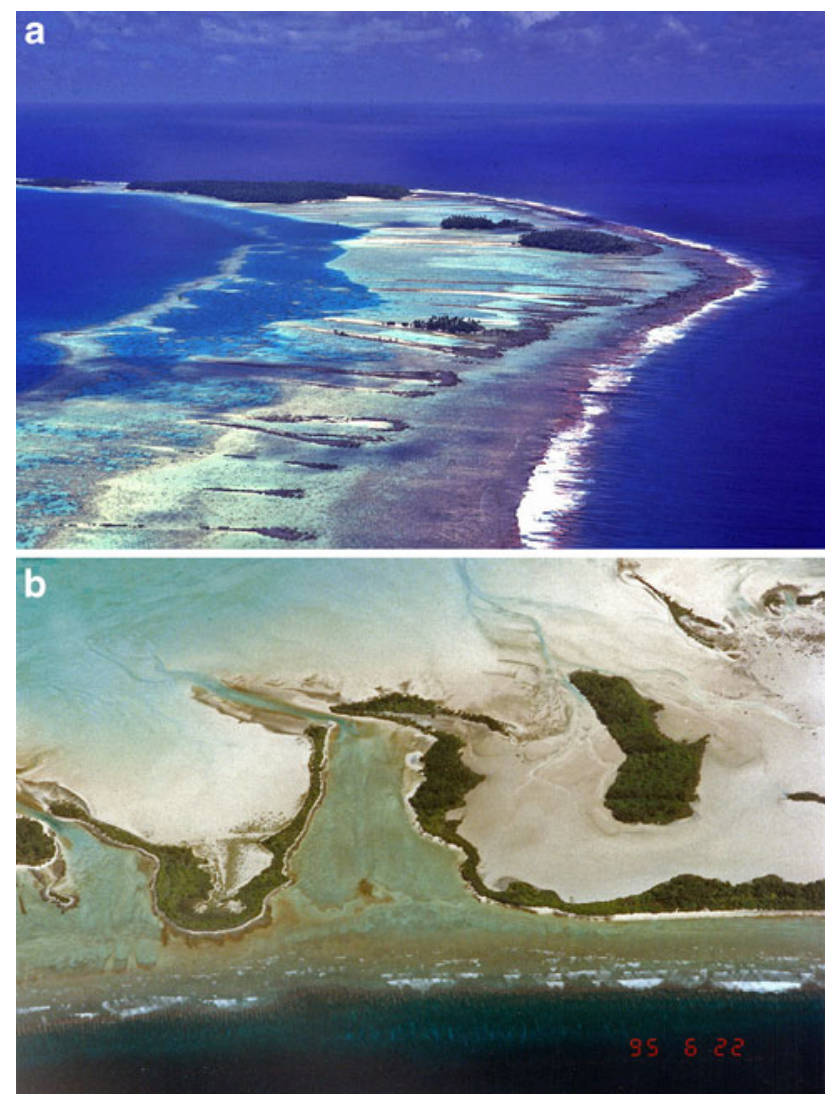

Fig. 5 a Southern reef rim of Manihiki, northern Cook Islands $(1,200 \mathrm{~km}$ north of Rarotonga), looking east toward the southeast corner of the atoll (photo courtesy SM Solomon 1996). b Northeast rim of Nonouti Atoll, Kiribati, $240 \mathrm{~km}$ south-southeast of Tarawa, looking onshore. Grooved forereef and reef crest in foreground with reef flat, complex reef islands and inter-island passages carrying sediment into the lagoon (background). Reef flat is approximately $250 \mathrm{~m}$ wide and main channel in middle of image is $500 \mathrm{~m}$ wide at near end (photo DLF 1995)

formed on older foundations since global sea level stabilized about 6,000 years ago (Bard et al. 1996). They have developed some degree of dynamic equilibrium with current climate and oceanographic environment, but are continually subject to readjustment, erosion and sedimentation, in response to varying sea levels, wind patterns, and storms.

Reef islands (Fig. 5a) develop on atoll margins, typically surrounding a central lagoon (Richmond 1992; Kench et al. 2005; Woodroffe 2008). In places these form a complete ring, but often they occupy only part of the reef rim, leaving large gaps (Fig. 4). Reef islands are typically elongate quasi-linear features $100-1,000 \mathrm{~m}$ wide with crests $<4 \mathrm{~m}$ above MSL and consist predominantly of unlithified or weakly cemented sediments derived from the reef, resting on a hard reef flat or cemented coral-rubble conglomerate. The dominant constituents of reef-island sediment vary from atoll to atoll, ranging from coral or crustose coralline algae to calcareous green algae
(Halimeda) and foraminifera. Foraminifera tend to predominate on Pacific atolls, while Halimeda is the dominant sediment source in the Caribbean (Yamano et al. 2005; Perry et al. 2011). On many atolls in the Pacific and eastern Indian Ocean, evidence of a higher Holocene sea level is preserved as fossil coral in growth position (Pirazzoli et al. 1988; Woodroffe et al. 1999; Woodroffe 2008). Exposures of slightly raised conglomerate in the shore zone provide some resistance to erosion and influence the planform shape of reef islands (Solomon 1997). Inter-island channels and passages interrupt the continuity of atoll rim islands and provide openings for lagoon water exchange and for sediment from the reef to be swept past the islands into the lagoon (Fig. 5b).

High carbonate islands including raised atolls

High carbonate-capped islands (Fig. 2) occur in forearc belts adjacent to subduction zones such as the Tonga Trench (Clift et al. 1998; Dickinson et al. 1999), the Cayman Trench (Perfit and Heezen 1978; Jones et al. 1997), and the Lesser Antilles arc-trench system (Bouysse et al. 1990). Structural segmentation of the Tonga Ridge has led to varying rates of uplift, subsidence, or tilting affecting individual blocks and islands (Dickinson et al. 1999). The thickness of the carbonate cap in the Cayman Islands is unknown but exceeds $400 \mathrm{~m}$ (Emery and Milliman 1980). Like the islands of the Tonga Ridge, these are believed to be on different fault blocks moving independently (Horsfield 1975; Jones and Hunter 1990). Barbados is another carbonate-capped high island, formed on the Lesser Antilles accretionary prism at the leading (eastern) edge of the Caribbean plate (Bouysse et al. 1990). Other high islands with wide barrier reefs, including Rodrigues (Mauritius) and Bermuda, have cemented calcareous windblown sand deposits that form high cliffs on exposed coasts. These are not easily categorized, having elements of at least three island types.

Contrasting examples of raised atolls include Aldabra in the Seychelles ( $\sim 8 \mathrm{~m}$ elevation, retaining a shallow central lagoon) and the isolated island of Niue in the South Pacific (up to $60 \mathrm{~m}$ elevation with a dry lagoon) (Fig. 6). Raised atolls such as Niue have extensive cave development (Fig. 7a). They are typically surrounded by terraces and cliffs, representing various phases of emergence, with a very narrow fringing reef on a wave-cut platform (Fig. 7b). With deep water immediately offshore, extreme waves overtopping the cliffs in major tropical cyclones are a significant hazard (Solomon and Forbes 1999).

\section{Continental islands}

A number of the world's tropical small to medium-sized islands are of continental origin (Fig. 2), including 
Fig. 6 Topography and bathymetry of Niue (Forbes 1996). Reproduced with permission from the Secretariat of the Pacific Community, New Caledonia

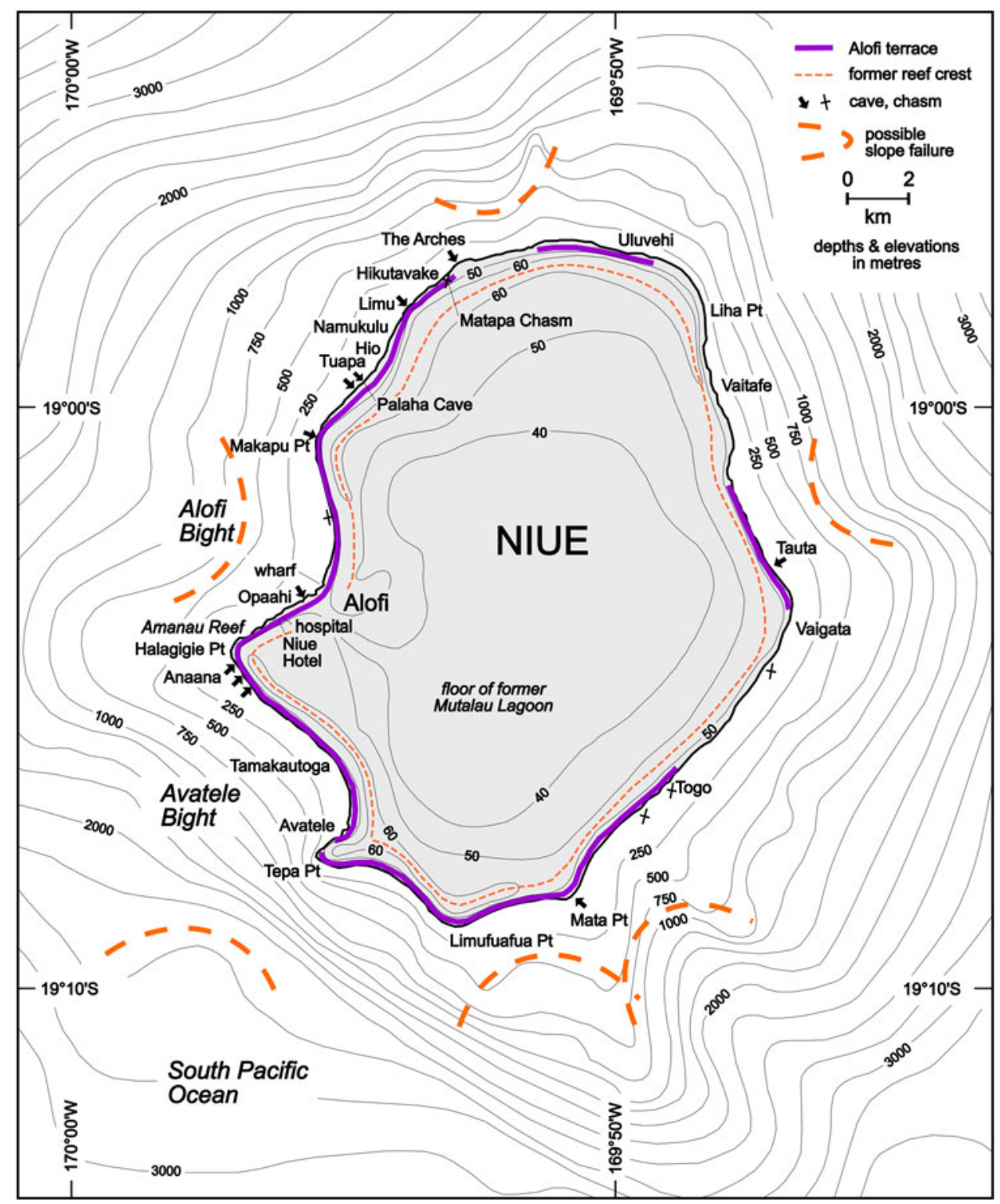

Trinidad (detached from South America) and New Caledonia (detached from Australia) (NC in Fig. 1). In the western Indian Ocean, the northern islands of the Seychelles archipelago (e.g., Mahé, Fig. 1) are composed predominantly of Precambrian granitic rocks (Fig. 8a) the subaerial parts of a micro-continent rifted from Madagascar (Collier et al. 2004). In contrast to the carbonate islands of the southwestern Seychelles, which rise from abyssal depths, the 40 granitic islands are surrounded by a shallow continental shelf covering an area about $300 \times 150 \mathrm{~km}$, where water depths are $<200 \mathrm{~m}$ (Jackson et al. 2005). The highest elevation, on the principal island of Mahé, is $905 \mathrm{~m}$. There is a discontinuous narrow coastal terrace, on which most development has occurred (Fig. 8b), and a fringing reef with a number of reef-gap beaches. In addition to coastal hazards, rockfall and landslides are a threat to development on the coastal terrace beneath steep slopes.

\section{Coastal hazards on small islands}

The nature of the hazards, exposure and vulnerabilitythus the most relevant adaptation measures-vary between island types in relation to elevation, but also to size, topography, bathymetry, lithology, reef morphology and ecological integrity, as well as human factors such as shore protection, or location and design of critical infrastructure and other property. The geographic region is important as it determines ocean climate (e.g., temperature and coral growth rate), storm climatology (including wind and wave patterns), and the regional trend of sea-level rise. Islands 
Fig. 7 a Section through raised reef rim and western coast of Niue (modified from Forbes 1996, after Jacobson and Hill 1980). b Cliff reentrant with thin pocket beach fronted by narrow reef at Hio on northwest coast of Niue (photo DLF 1995). Note prominent fracture in cliff extending partway across basal platform; cliff is $18 \mathrm{~m}$ high at this location (Forbes 1996). Permissions: a ${ }^{\odot}$ Commonwealth of Australia (Geoscience Australia) 2013; this product is released under the Creative Commons Attribution 3.0 Australia Licence. a, b Reproduced with permission from the Secretariat of the Pacific Community, New Caledonia
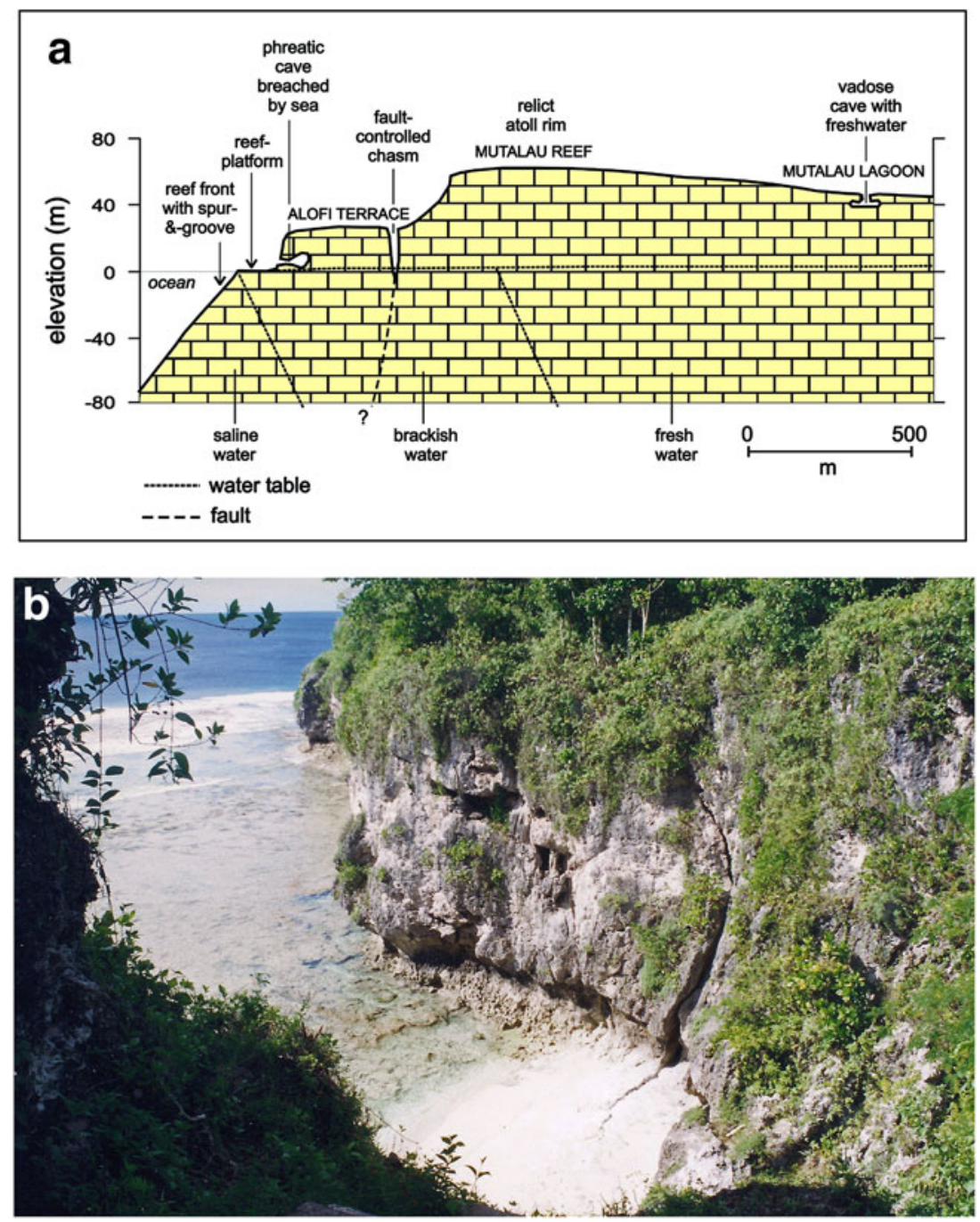

within $\pm 5^{\circ}$ latitude about the equator are generally free of tropical cyclones, but occasional storm incursions, exceptional winds, or impacts of far-travelled swell from midlatitude storms can cause significant damage, the effects of which are also influenced by sea-level variability resulting from El Niño-southern oscillation (ENSO) or other largescale climate cycles. At tropical to mid-latitudes $>5^{\circ}$ (north or south), tropical cyclones are a major recurring threat (Hay and Mimura 2010). In addition to climate effects, geophysical hazards such as volcanic eruptions, landslides, earthquakes and tsunami require attention and may pose equal or greater risks to island communities.

Apart from catastrophic events, coastal stability is a function of wave energy, erodibility, and sediment supply, which may depend on reef health and the production of biogenic sand (Kench and Cowell 2001; Perry et al. 2008, 2011). Reefs represent not only a source of sediment, but play a major protective role, absorbing much of the deepwater wave energy. There is cause for concern about the mid-term fate of coral reefs (e.g., Hoegh-Guldberg et al.
2007), but recent work has shown that the coralline algae forming the resistant rims of some reefs may be more resistant to acidification than previously thought (Nash et al. 2013). In some places, exposure is mitigated and resistance to erosion increased where mangroves are present along the shore. Removal of mangroves can often be identified as a source of erosion problems in coastal communities (Mimura and Nunn 1998; Solomon and Forbes 1999).

Geological hazards: volcanoes, earthquakes, slope instability and tsunami

Low-lying communities on high islands with shallow coastal waters that promote tsunami shoaling may have relatively high exposure to far-travelled tsunami (Jackson et al. 2005). In contrast, small islands such as atolls on pinnacles rising from abyssal depths may derive some protection due to minimal shoaling. The Indian Ocean tsunami of December 2004 caused extensive damage on 


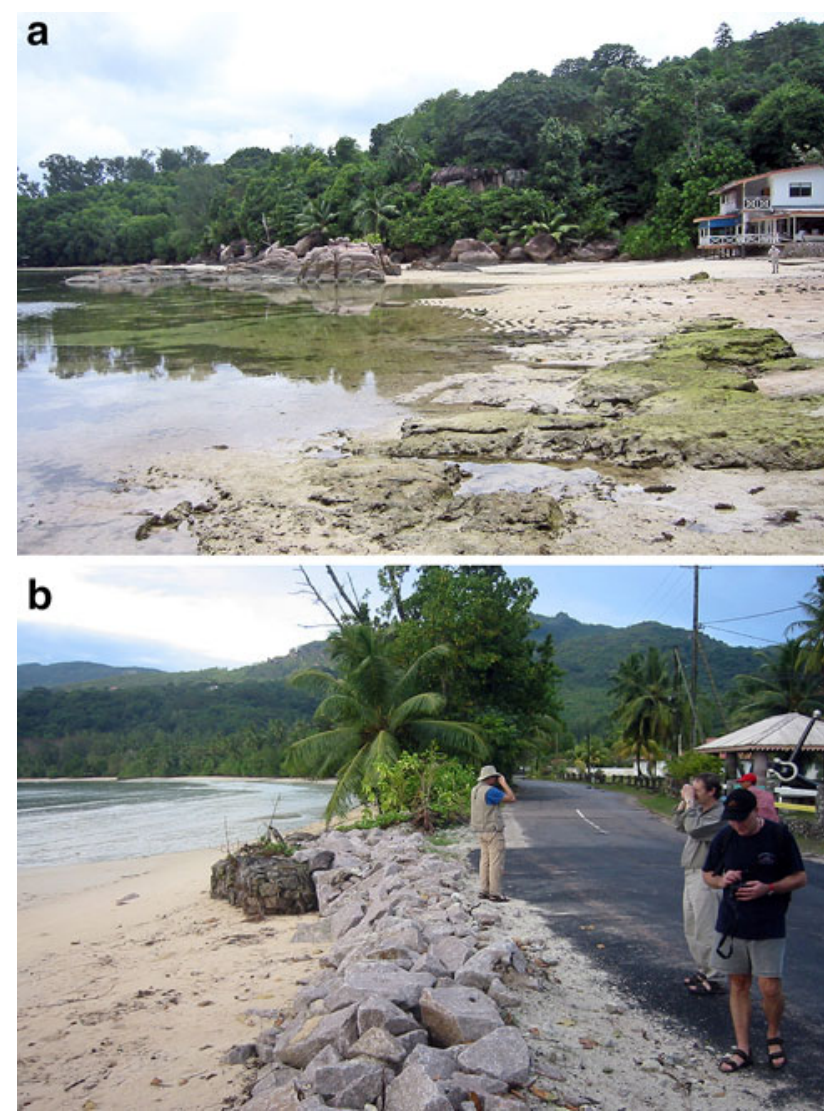

Fig. 8 a Reef-fronted beach with outcrop of granite and beachrock (foreground), east coast of high island of Mahé, Seychelles (photo DLF 2005). Note hotel overhanging seawall and beach. b Development on coastal terrace, Baie de la Mouche, west coast of Mahé, where natural berm has been removed for road construction: tsunami damage occurred here in 2004 (photo DLF 2005)

coastal terrace infrastructure in the high islands of the Seychelles. The shallow continental shelf promoted shoaling and refraction or diffraction to the back side of islands such as Mahé (Fig. 8b), while atolls of the southern Seychelles in deep water were largely unaffected (Shaw et al. 2005). Not all atolls in the Indian Ocean were thus protected. The same event inundated numerous atolls in the Maldive Islands, causing runup to $1.8 \mathrm{~m} \mathrm{MSL}$ in South Maalhosmadulu Atoll (Kench et al. 2006). The location of this island on a broad carbonate bank with depths $<500 \mathrm{~m}$ may have contributed to shoaling and exacerbated the impact. Elsewhere in the Maldives, overland flow depths up to $4 \mathrm{~m}$ were documented (Fritz et al. 2006).

The foregoing observations pertain to large-scale basincrossing tsunami such as the 2004 event in the Indian Ocean or its 1833 equivalent (Zachariasen et al. 1999; Shaw et al. 2005). The 1755 Lisbon earthquake and a lesser event in 1761 are the only trans-oceanic tsunami reported in the Caribbean in the past 600 years (O'Loughlin and Lander 2003). On the other hand, regional and locally generated tsunami pose a critical threat to low-lying settlements and infrastructure in many island settings, particularly in the Caribbean, where of 85 recorded tsunami events since 1498, 17 have caused in total more than 15,000 human fatalities (Harbitz et al. 2012). Caribbean tsunami result from earthquakes along the Caribbean plate boundary, from related volcanic eruptions in the Lesser Antilles, and from onshore and submarine landslides. The highest tsunami in the region, resulting from an 1867 Virgin Islands earthquake, affected all the islands in the Lesser Antilles, with recently reassessed runup heights ranging up to $10 \mathrm{~m}$ (Harbitz et al. 2012). Slope instabilities on the flanks of active volcanic islands such as Tenerife in the Atlantic (e.g., Krastel et al. 2001) or La Réunion in the Indian Ocean (Oehler et al. 2008) constitute another major tsunami hazard and may result from dome or flank collapse, pyroclastic debris flows (lahars), or explosive submarine eruptions. There are 12 active volcanoes in the 10 major inner-arc islands of the Lesser Antilles and catastrophic flank collapse is a significant hazard (e.g., Boudon et al. 2007; Le Friant et al. 2006, 2009). Many island coasts in the Lesser Antilles have cliffs cut into volcano flank slopes-displacement of landslide blocks into the ocean is recognized as another major tsunami trigger. With the closely spaced islands in this region, tsunami travel times are short. Teeuw et al. (2009) estimate that up to 30,000 people on the south coast of Guadeloupe, $40-60 \mathrm{~km}$ to the north, are at risk from potential slope failure on Dominica. Locally generated tsunami are also recognized as a hazard in the Pacific, where coastal communities have been devastated by tsunami from nearby submarine slope failure (e.g., McAdoo et al. 2009). The 2009 Tonga Trench earthquake caused tsunami runup as high as $17 \mathrm{~m}$ in Samoa and $22 \mathrm{~m}$ in northern Tonga, causing 189 fatalities (Fritz et al. 2011).

\section{Oceanographic hazards: waves and storm surges}

Reefs surrounding tropical small islands provide a major service as shore protection in addition to their role as sources of sediment and nourishment for island communities. The outer reef rim absorbs a large proportion of wave energy. Gourlay (1994) showed that the nature of wave breaking on the outer reef determines the transmission of deep-water wave energy, with more than $80 \%$ of the energy absorbed by plunging breakers. Wave set-up over reef flats is a function of deep-water wave height and period, still-water depth over the flat, and the morphology of the reef crest, while the energy decay across the reef flat is a function of width and roughness (Massel and Gourlay 2000; Sheppard et al. 2005). With increased depth over the reef crest, either through coral mortality and degradation (Sheppard et al. 2005) or from physical causes such as storm surge, ENSO variability, or sea-level rise, a higher 
proportion of wave energy can cross the reef to reach island shores. Waves overtopping the reef also generate currents, which can contribute to wave-driven sediment transport toward the shore or alongshore (Forbes 1995; Kalbfleisch and Jones 1998), with implications for island transformation through differential erosion and sedimentation (Webb and Kench 2010). Where large reef gaps occur, wave energy dissipation may be lower, allowing higher waves at the shore. A comparison of beach ridge, berm, and top-ofbeach elevations for various island types and settings shows that crest elevations on reef-gap beaches exposed to Southern Ocean swell, such as Natadola Beach in Fiji (Forbes et al. 1995), are rarely the highest observed (Fig. 9). There are many examples of single storms constructing massive rubble ridges on atolls and fringing reefs of high islands (e.g., McKee 1959; Maragos et al. 1973; Baines and McLean 1976; Scoffin 1993; Solomon and Forbes 1999; Scheffers 2005). Morton et al. (2006) provide a useful literature review and illustrations of storm ridges from various islands and regions.

Wave overtopping and ocean flooding are major hazards on low-lying atolls under storm conditions (Scoffin 1993). Tropical storm surges and waves can overwhelm island communities, as occurred at Manihiki (Fig. 5a), northern Cook Islands, during passage of Cyclone Martin in November 1997-only four houses were left standing in the two island villages and 20 residents were lost (de Scally

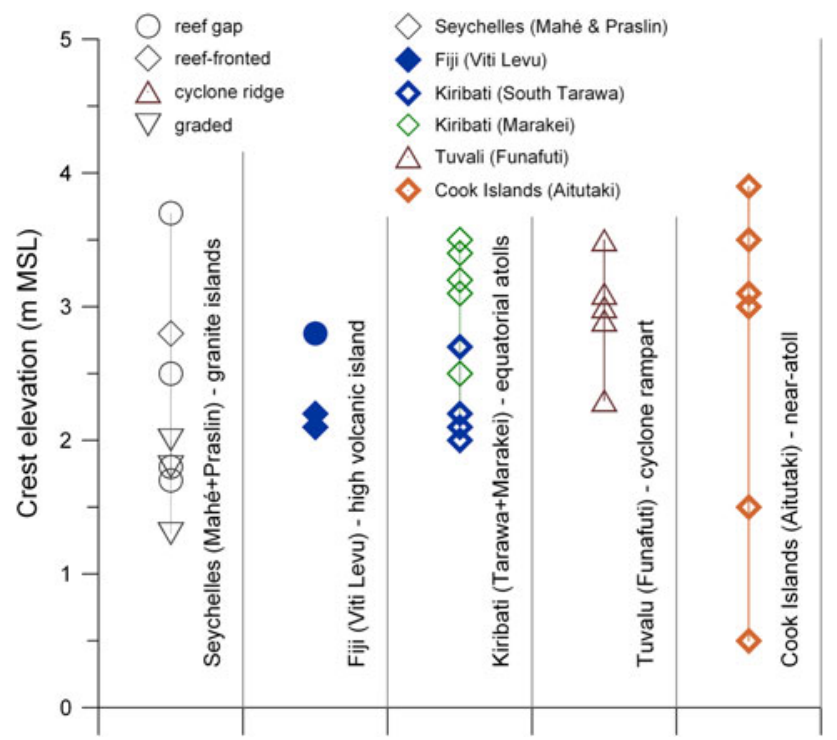

Fig. 9 Berm-crest elevations representing run-up limits for various island groups and types. Data sources: for high granite islands of Seychelles (Jackson et al. 2005); for Natadola Beach on Fijian volcanic island of Viti Levu (Forbes et al. 1995); for equatorial atolls in Kiribati (Tarawa: Forbes and Biribo 1996; Marakei: Woodroffe 2008); for storm ridge on Funafuti, Tuvalu (Baines and McLean 1976); for near-atoll of Aitutaki in southern Cook Islands (Forbes 1995)
2008). Maragos et al. (1973) provide a graphic description of flooding and wave overtopping on Funafuti Atoll, Tuvalu, during Cyclone Bebe in October 1972.

Forbes (1996) and Solomon and Forbes (1999) described storm impacts from Cyclone Ofa in 1990 on the raised island of Niue (Fig. 7). Numerous facilities on top of coastal cliffs up to $25 \mathrm{~m}$ high were damaged severely by storm waves breaking against the cliffs. Many of these facilities were repaired, only to be damaged even more severely by category 5 Cyclone Heta 14 years later. Thus, while raised atolls are largely immune to storm flooding, their narrow reef fringe, allowing deep-water waves to break almost directly against the cliffs, exposes cliff-top infrastructure and properties to extraordinary wave impact.

Sea-level rise and variability

Atolls and the low-lying terraces of high islands are susceptible to more frequent or higher flooding under climateinduced acceleration of global mean SLR. Deepening of water over reefs may increase wave energy at the shoreline and salt water may intrude into island soils and aquifers. Sea-level variability due to ENSO or other large-scale circulation, as well as tides and storm surges, all ride on the MSL. Thus it is important to develop robust projections of local SLR for individual regions and islands. These require knowledge of the global drivers as well as local factors such as uplift or subsidence rates. There is a growing consensus that the SLR projections of the IPCC (2007) AR4 were conservative and that SLR this century is likely to exceed AR4 estimates (Rahmstorf et al. 2007; Rahmstorf 2010; Church and White 2011). Post-AR4 projections of twenty-first century global mean SLR range up to $1.4 \mathrm{~m}$ or more but less than $2 \mathrm{~m}$ (Rahmstorf 2007, 2010; Pfeffer et al. 2008; Grinsted et al. 2009; Jevrejeva et al. 2010, 2012; Rahmstorf et al. 2012b).

Church et al. (2004, 2008), Church and White (2006, 2011), Domingues et al. (2008), Jevrejeva et al. (2008), Cazenave and Llovel (2010) and others have documented the slow rise of GMSL since the nineteenth century, slow or intermittent acceleration through the twentieth century, and more rapid acceleration over the past two decades. Meanwhile, satellite altimetry over the ocean basins since 1993 has revolutionized the monitoring of GMSL (Leuliette et al. 2004), showing an upward trend well correlated with the tide-gauge reconstruction that suggests an acceleration to $3.2 \pm 0.4 \mathrm{~mm} \mathrm{year}^{-1}$ (1993-2009) from the mean rate of $1.9 \pm 0.4 \mathrm{~mm} \mathrm{year}^{-1}$ since 1961 (Church and White 2011).

Knowledge of the past and present rates of sea-level rise at small islands in all oceans is constrained by the sparse tidegauge network and the paucity of long, stable, and continuous records (Church et al. 2006; Sutherland et al. 2008). Trends 
derived from shorter records can be highly misleading, because they may not resolve the effects of decadal or subdecadal variability such as ENSO or the North Atlantic Oscillation (NAO), among others. ENSO changes can cause monthly MSL anomalies of several decimetres. Figure 10 shows time series of annual means for GMSL and island tide gauges in three oceans (Mauritius, Tarawa, and Bermuda). These demonstrate high interannual to decadal-scale variability, particularly at Tarawa in the 1990s, where MSL dropped $45 \mathrm{~cm}$ from March 1997 to February 1998 (Donner 2012). Mauritius shows much lower variance, as does Bermuda since 1980. However, the Bermuda record shows a higher range (almost $0.2 \mathrm{~m}$ in the annual means) in the $1960 \mathrm{~s}$ and 1970 s, possibly reflecting the predominantly negative NAO at that time. These examples make clear that short-term variability in sea levels is superimposed on longer-term trends and needs to be considered in adaptation planning (Jevrejeva et al. 2006; Rahmstorf 2012).

Robust projections of future MSL on tropical small islands are constrained by several issues affecting both GMSL and regional deviations from the global mean. These include:

- the range of emission scenarios and associated global sea-level projections in the most recent IPCC reportthe AR4 at the time of writing (Meehl et al. 2007);

- remaining uncertainties in the spatial distribution of future sea-level change (a function of uncertainties in the relative contributions of the Greenland and Antarctic ice sheets, large ice caps and mountain glaciers in various regions);

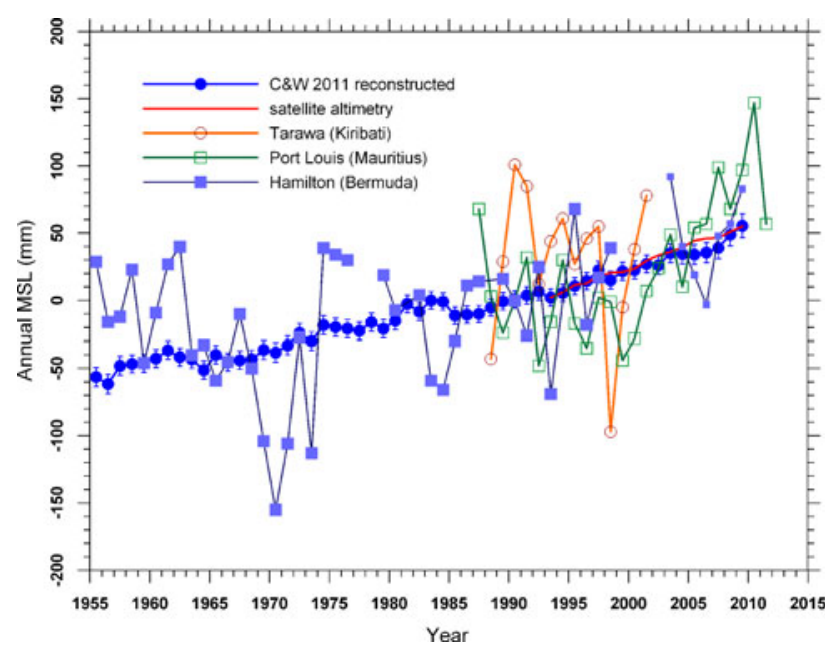

Fig. 10 Annual global mean sea level (GMSL) as reconstructed from tide-gauge data (Church and White 2011), 1955-2009, and global mean from satellite altimetry. Also shown are annual mean sea level (MSL) data for Port Louis (Mauritius), Tarawa (Kiribati), and Hamilton (Bermuda). Global reconstructed and satellite data from CSIRO (http://www.cmar.csiro.au/sealevel/sl_data_cmar.html). Station data from PSMSL (http://www.psmsl.org/data/)
- poorly constrained changes in ocean circulation or changes in the intensity of ENSO, NAO, or other largescale oscillations that can influence regional sea levels;

- limited data (absent for many islands) on rates of vertical land motion and large uncertainties where the geodetic time series are short (Table 1).

A growing number of global navigation satellite system (GNSS) installations and increasing record lengths go some way to alleviate the sparse data on island motion. However, many islands have no measurements and the differing vertical motion of adjacent islands noted earlier precludes extrapolation from nearby island stations. Because vertical land motion can be of the same order of magnitude as sealevel change, the lack of information introduces large uncertainties into projections of local sea-level rise (Fig. 11).

GMSL has been tracking close to the upper limit of the IPCC (2007) projections over the past decade and more (Fig. 10) (Rahmstorf et al. 2007, 2012a). This suggests that the B1 scenario lower-limit projections (Table 1; Fig. 11) severely underestimate future sea levels, as they are comparable to the late twentieth century mean SLR prior to the more recent acceleration. Figure 11 also shows the upper limit projections for the fossil-fuel intensive A1FI scenario, both without ( $\left.\mathrm{A}_{1 \mathrm{FI}} \mathrm{MAX}\right)$ and with $\left(\mathrm{A} 1 \mathrm{FI}_{\mathrm{MAX}}+\right)$ the contribution of accelerated glacier outflow from the major ice sheets (Meehl et al. 2007). It also shows the range of a semi-empirical projection derived from Rahmstorf (2007) and Grinsted et al. (2009), equivalent to $1.15 \mathrm{~m}$ globally over 90 years (James et al. $2011)$, for various meltwater source scenarios $\left(R_{\mathrm{MIN}}\right.$ to $\left.\mathrm{RG}_{\mathrm{MAX}}\right)$. These projections incorporate observed trends and uncertainty in vertical crustal motion (Table 1; Fig. 11 grey bars with error bars). Using these scenarios, we see that the projected MSL changes over the 90 years 2010-2100 have ranges of 3-43 cm $\left(B 1_{\mathrm{MIN}}\right), 39-80 \mathrm{~cm}$ $\left(\mathrm{A} 1 \mathrm{FI}_{\mathrm{MAX}}\right)$, and $56-101 \mathrm{~cm}\left(\mathrm{~A} 1 \mathrm{FI}_{\mathrm{MAX}}+\right)$ for the islands considered here (Fig. 1). However the uncertainty in vertical motion translates to uncertainties in these SLR projections ranging from 5 to $67 \mathrm{~cm}$ (Table 1). For the semi-empirical model, the highest local projections $\left(\mathrm{RG}_{\mathrm{MAX}}\right)$ have a range of $106-156 \mathrm{~cm}$ (Table 1$)$. A large part of the variability between sites is a function of vertical motion, although the redistribution of meltwater in the oceans ('sea-level fingerprinting') also contributes.

Island vulnerability to sea-level rise and storms

Much of the concern about accelerating SLR centers on the question of whether reef islands on atolls will be lost 
Table 1 Ninety-year projections (2010-2100) of relative sea-level rise (SLR) for 18 selected island sites in the Indian, Pacific, and Atlantic Oceans together with measurements of local vertical crustal motion $(\mathrm{VM})$ and uncertainty $\left( \pm 1 \mathrm{~s}_{\mathrm{VM}}\right)$ on crustal motion (all in meters over 90 years) $\mathrm{B} 1_{\mathrm{MIN}}$ and $\mathrm{A} 1 \mathrm{FI}_{\mathrm{MAX}}$ are the minimum and maximum projections from the IPCC (2007) and $\mathrm{AlFI}_{\mathrm{MAX}}+$ is the upper limit for the A1FI SRES scenario augmented to account for accelerated drawdown of ice sheets (Meehl et al. 2007)

\begin{tabular}{|c|c|c|c|c|c|c|c|}
\hline Location & $\begin{array}{l}\mathrm{B} 1_{\mathrm{MIN}} \\
(\mathrm{m})\end{array}$ & $\begin{array}{l}\mathrm{A} 1 \mathrm{~F} 1_{\mathrm{MAX}} \\
(\mathrm{m})\end{array}$ & $\begin{array}{l}\mathrm{A}_{1 \mathrm{FI}} \mathrm{MAX}+ \\
\text { (m) }\end{array}$ & $\begin{array}{l}\mathrm{RG}_{\text {MAX }} \\
(\mathrm{m})\end{array}$ & $\begin{array}{l}\mathrm{RG}_{\mathrm{MIN}} \\
(\mathrm{m})\end{array}$ & $\begin{array}{l}\mathrm{VM} \\
(\mathrm{m})\end{array}$ & $\begin{array}{l} \pm \mathrm{s}_{\mathrm{VM}} \\
(\mathrm{m})\end{array}$ \\
\hline Mahé (Seychelles) & 0.15 & 0.52 & 0.72 & 1.23 & 1.21 & -0.01 & 0.21 \\
\hline Port Louis (Mauritius) & 0.23 & 0.60 & 0.80 & 1.32 & 1.30 & -0.09 & 0.22 \\
\hline Malé (Maldives) & 0.42 & 0.79 & 0.99 & 1.50 & 1.46 & -0.29 & 0.39 \\
\hline Diego Garcia (UK) & 0.11 & 0.48 & 0.68 & 1.21 & 1.18 & 0.03 & 0.07 \\
\hline Cocos-Keeling (Australia) & 0.31 & 0.68 & 0.89 & 1.41 & 1.39 & -0.18 & 0.13 \\
\hline Melekeok (Palau) & 0.10 & 0.47 & 0.68 & 1.20 & 1.17 & 0.03 & 0.20 \\
\hline Guam (United States) & 0.13 & 0.50 & 0.71 & 1.25 & 1.21 & 0.01 & 0.08 \\
\hline Majuro (Marshall Islands) & 0.03 & 0.41 & 0.62 & 1.18 & 1.13 & 0.10 & 0.20 \\
\hline Tarawa (Kiribati) & 0.09 & 0.47 & 0.69 & 1.24 & 1.21 & 0.04 & 0.10 \\
\hline Funafuti (Tuvalu) & 0.16 & 0.54 & 0.75 & 1.31 & 1.28 & -0.03 & 0.07 \\
\hline Alofi (Nuie) & 0.42 & 0.80 & 1.01 & 1.56 & 1.55 & -0.29 & 0.21 \\
\hline Rarotonga (Cook Islands) & 0.14 & 0.52 & 0.73 & 1.28 & 1.26 & -0.01 & 0.06 \\
\hline Tahiti (France) & 0.14 & 0.52 & 0.74 & 1.29 & 1.27 & -0.01 & 0.05 \\
\hline Hamilton (Bermuda) & 0.28 & 0.61 & 0.78 & 1.30 & 1.24 & -0.14 & 0.09 \\
\hline West End (Bahamas) & 0.05 & 0.39 & 0.56 & 1.06 & 1.03 & 0.09 & 0.67 \\
\hline St. Croix (US Virgin Islands) & 0.31 & 0.66 & 0.85 & 1.36 & 1.34 & -0.17 & 0.14 \\
\hline Bridgetown (Barbados) & 0.39 & 0.75 & 0.93 & 1.44 & 1.43 & -0.25 & 0.21 \\
\hline Grande Rivière [Trinidad and Tobago] & 0.05 & 0.40 & 0.59 & 1.09 & 1.08 & 0.09 & 0.63 \\
\hline
\end{tabular}

$\mathrm{RG}_{\mathrm{MAX}}$ and $\mathrm{RG}_{\mathrm{MIN}}$ are the maximum and minimum values for a range of source attribution and fingerprinting scenarios for a semi-empirical projection of $1.15 \mathrm{~m}$ global mean sea level (GMSL) rise over 90 years (Rahmstorf 2007; Grinsted et al. 2009; cf. James et al. 2011)

Global 90-year sea-level rise: $\mathrm{B} 1_{\mathrm{MIN}}=0.15 \mathrm{~m} ; \mathrm{A} 1 \mathrm{FI}_{\mathrm{MAX}}=0.51 \mathrm{~m} ; \mathrm{A} 1 \mathrm{FI}_{\mathrm{MAX}}+=0.69 \mathrm{~m} ; \mathrm{RG}=1.15 \mathrm{~m}$

through erosion and flooding in future decades. The low elevation of atoll islands and their resident communities is a serious constraint. The area higher than 2 (3) m MSL accounts for $34 \%(7 \%)$ of total land area in the Gilberts (Kiribati) and Tuvalu, $33 \%(8 \%)$ in the Cocos (Keeling) Islands, $28 \%$ (7 \%) in Diego Garcia, and only $4 \%$ (1\%) in the Maldives (Woodroffe 2008). In general, low atoll elevations facilitate inundation by SLR and flooding by extreme tides, anomalous high water episodes (e.g., El Niño), and storms (Maragos et al. 1973; Yamano et al. 2007; Donner 2012). As discussed above, wave energy on reef island shores is limited by energy loss at the outer reef and controlled by depth over the reef rim and flat. It follows that rising sea levels may produce higher wave energy at reef-island shores, which could lead either to erosion or island washover and aggradation. Recent evidence points to the dynamic resilience of reef islands in the face of twentieth century SLR, as sediment is retained within the atoll and erosion on one part of a reef island may be largely balanced by deposition on another part (Webb and Kench 2010). It is also clear that, with a positive sediment budget, reef islands can accrete on the ocean side as sediment from the reef rim is transported onshore (Woodroffe et al. 2007;
Woodroffe 2008; Perry et al. 2011). Atolls such as Nonouti (Fig. 5b), with numerous passages from the reef flat to the lagoon through inter-islet channels, may see a large proportion of sediment production from the reef transferred to the lagoon or alongshore off the end of the islet-chain (Forbes and Biribo 1996). This may contribute to erosion of ocean-side shores in some sectors. Therefore, although reef islands may aggrade through wave runup and overtopping so long as vertical growth of the reef can keep pace with future SLR, the specific response of individual atolls and islets within atolls will depend to a large extent on the local morphodynamics. Wave overtopping events damage infrastructure and create safety concerns, but can gradually raise island elevations, unless blocked by shore protection structures (Kench 2012).

A key question is the vertical growth potential of the reef, which may be diminished by elevated temperatures, ocean acidity, pollution and nutrient enrichment, sediment influx or resuspension, physical disruption by major storms or human activities, or excessive exploitation of key species (Smith and Buddemeier 1992; HoeghGuldberg et al. 2007; Perry et al. 2011, 2013). The morphology and species composition of the reef, wave 


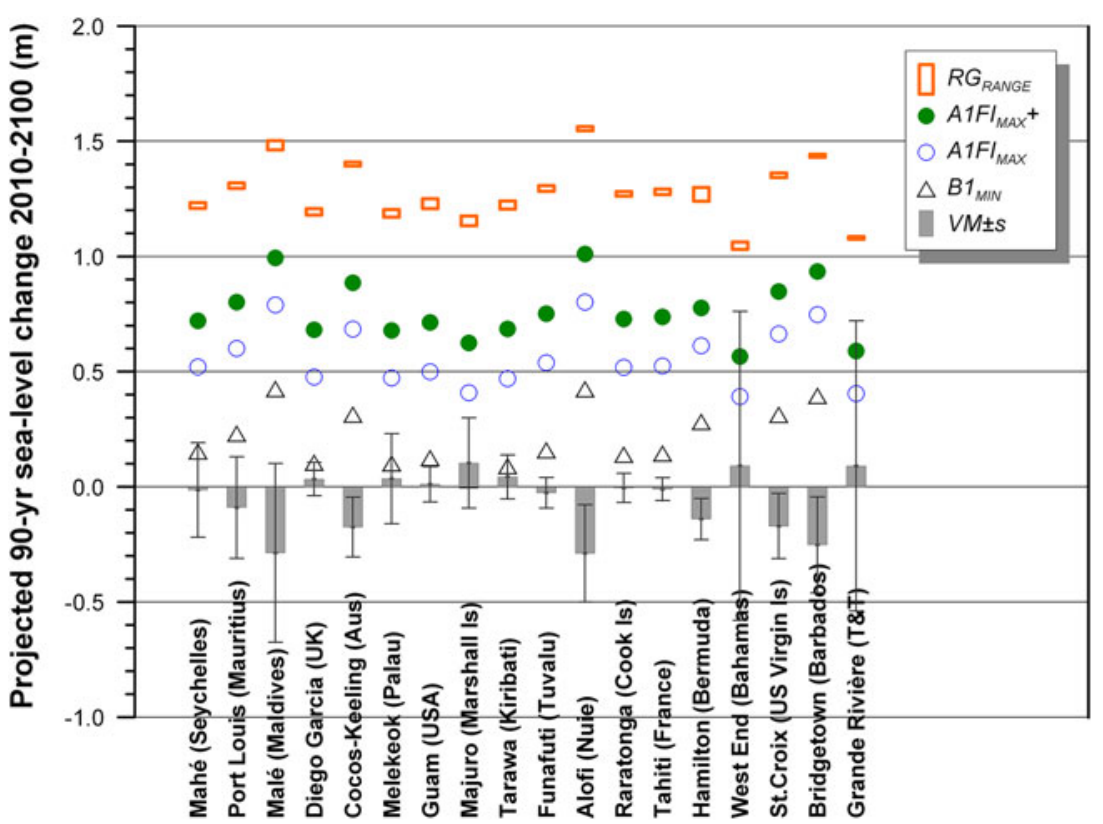

Fig. 11 Ninety-year (2010-2100) projections of local relative SLR for 18 island sites in the Indian, Pacific, and Atlantic basins (see Fig. 1 for locations), for a range of scenarios with computed meltwater redistribution ('sea-level fingerprinting'). Projections incorporate measured vertical motion (grey bars with error bars) derived from Jet Propulsion Laboratory (JPL) data (see text and Table 1). The lowest three projections are based on the Intergovernmental Panel on Climate Change Fourth Assessment Report (IPCC

energy, nutrient flux, and depth are all factors that affect the vertical growth rate (Adey 1978; Chappell 1980; Woodroffe 2002). There is new evidence to suggest that rapid reef accretion can occur with high terrigenous sediment input (Perry et al. 2012) but reef health and biodiversity may be compromised. Beyond the physical and biological status of the reef, there is a need to understand the limitations on productivity of other key island sediment constituents, notably foraminifera in the Pacific and Halimeda in the Caribbean (McClanahan et al. 2002; Yamano et al. 2005).

The habitability of low-lying atolls and reef islands is critically dependent on the availability of fresh water. Freshwater aquifers on reef islands are shallow lenses overlying brackish and saline water. Shoreline changes, particularly erosion and loss of island area, can negatively affect the freshwater lens and saline contamination can occur when major storms overflow island communities (Maragos et al. 1973; Solomon 1997). Under these circumstances, saltwater can flow into open wells and percolate directly into the highly permeable island soils. Much work has been done on the engineering of freshwater systems and assessment of freshwater demand, but a full understanding of water vulnerability under climate change or catastrophic storms is lacking for many islands (e.g., Schwerdtner Máñez et al. 2012).
AR4) (Meehl et al. 2007): $\mathrm{B} 1_{\mathrm{MIN}}$ is the lower limit of the special report on emission scenarios (SRES) B1 projection; $\mathrm{A}_{1 \mathrm{FI}} \mathrm{MAX}$ is the upper limit of the SRES A1FI projection; $\mathrm{A}_{1 \mathrm{FI}} \mathrm{MAX}^{+}$is the upper limit of A1FI with accelerated ice-sheet drawdown. The upper projection (boxes) shows the range for different source region scenarios for a semi-empirical projection equivalent to a mean rise of $1.15 \mathrm{~m}$ over 90 years, $\mathrm{RG}_{\mathrm{MIN}}$ and $\mathrm{RG}_{\mathrm{MAX}}$ (see text)

\section{Discussion}

This review demonstrates that tropical small islands are subject to a wide range of physical forcing and that island shoreline stability is dependent in large part on the maintenance of healthy coastal ecosystems. The range of coastal hazards identified here highlights the substantial exposure of some island communities. At the same time, it is clear that coral growth, biogenic sediment production, and wave action can serve to maintain stability and even contribute to island growth, this being the way in which reef islands were formed in the first place. Thus it is clear that development and adaptation strategies (e.g., ecosystem-based adaptation) designed to complement natural resilience in the coastal system should have a higher probability of success. This approach presupposes an understanding of the relevant coastal sedimentary and ecological processes of interest, which highlights the importance of biophysical science as one component of the information package needed for effective coastal management, climate-change adaptation, and disaster risk reduction. In a broader governance context, it is recognized that understanding of key processes forms an essential foundation for sustainable development (Glaser et al. 2012).

Effective disaster risk reduction also requires knowledge of potential threats. In some cases, for rare and exceptional 
events such as major tsunami or extreme storms, there may be some residual community memory, but often there is not. Effective stakeholder collaboration and attention to local and traditional knowledge are important and may identify issues that would otherwise be overlooked. There is a large and growing literature on the value of indigenous knowledge and protocols for integrating locally sourced information with other forms of knowledge including western scientific approaches (e.g., Crump and Kelman 2009; Kelman and West 2009; McAdoo et al. 2009; Mercer et al. 2009). The explosive growth of social media, even in remote communities, opens up new possibilities for information exchange and participatory dialogue. New tools are being developed to invite and enable contributions of information from the wider public (e.g., Tienaah 2011; Nichols et al. 2011).

This study has highlighted the variability of island environments and the diversity of dominant processes, hazards, and exposure on various island types. As shown schematically in Fig. 12, differences in the modes of exposure and dominant hazard issues between island types can be correlated to variations in the relative importance and utility of adaptation actions. Thus, an ecosystem-based adaptation tool such as mangrove conservation or restoration is applicable to continental and volcanic high islands and locally on atolls, but irrelevant on raised carbonate atolls. Coastal setback is a globally recognized proactive adaptation option applicable to all island types, but perhaps most compelling on high carbonate islands such as Bermuda or Niue, where major tropical cyclone waves can demolish cliff-top facilities.

The island typology can provide a template (checklist) of potential hazards and the nature of potential impacts, but our review has highlighted the critical importance of local place-based analysis of the coastal biophysical and socialecological systems. Understanding shoreline stability on atoll islands and projecting long-term land availability under various climate-change scenarios requires detailed data on coastal morphology, including high-resolution digital elevation models, and on the processes that drive coastal change. In this context, Woodroffe (2008) pointed to a number of specific knowledge requirements. He noted the need to watch for thresholds that might lead to major transformations in the nature and stability of reef and shore systems. Webb and Kench (2010), reporting an analysis of multi-decadal island shoreline change, concluded that "island nations must place a high priority on resolving the precise styles and rates of change that will occur over the next century and reconsider the implications for adaptation". In another context, evaluating the stability and size of potential tsunami-generating landslide blocks on heavily forested volcanic island slopes in Dominica, Teeuw et al.
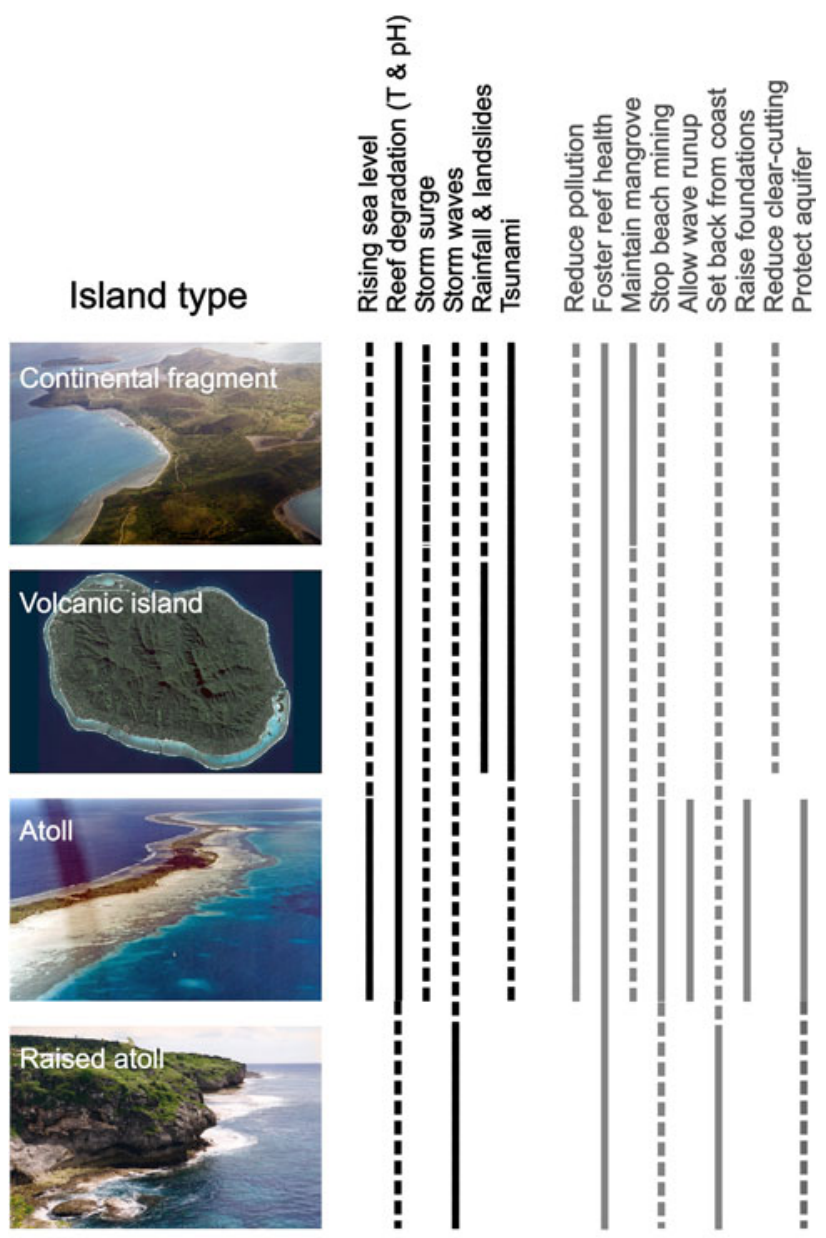

\section{Hazard severity}

Fig. 12 Schematic template showing variable severity of major coastal hazards as a function of island type and a selection of adaptation strategies with varying applicability across types. Photos (from top): near Tongouin, New Caledonia (DLF 1997); Rarotonga, Cook Islands (NASA, Fig. 3); South Tarawa, Kiribati (DLF 1995); Alofi, Niue (DLF 1995)

(2009) identified mapping with suitable tools as a prime requirement.

Other critical data needs have also emerged from this study. It is evident that measurements of vertical crustal motion are a prerequisite for robust projections of future sea levels at any specific island site (Fig. 11). Long-term water level records from tide gauges are equally important, even when complemented by satellite altimetry (Davis et al. 2012). Yet the network of GNSS stations on islands worldwide is extremely sparse and the number of colocated GNSS and tide gauges is even smaller. Even where data are available, as at many of the 18 sites used for SLR projections in this study (Fig. 1), continuity is a challenge and very few islands are represented in the active network 
of the International GNSS Service (http://www.igs.org/net work/netindex.html).

\section{Conclusions}

Realistic physical hazard and impact projections are a prerequisite for effective adaptation planning. The hazard mix and severity may vary with island type and regional setting. There is a need for monitoring of evolving physical exposure to provide objective data on island responses and early warning of changing risk. Reef islands may be resilient under rising sea level, at least at rates experienced during the twentieth century, maintaining island area but not necessarily fixed shoreline positions. The latter has implications for land ownership, property boundaries, and shorefront infrastructure. Coastal stability requires maintenance of healthy coastal ecosystems, particularly in tropical regions where organisms produce sand. Degradation of protective reefs will increase exposure to erosion. Effective adaptation to SLR requires realistic projections, which need to incorporate the latest climate science, knowledge of vertical motion, regional ocean dynamics, and meltwater redistribution in the oceans. A precautionary approach requires robust island-specific projections of the full range of potential sea-level scenarios and future updating as new insights and consensus develop through the coming decade and beyond. Ultimately there is a need for placebased studies incorporating objective science and indigenous knowledge to build an understanding of the specific processes operating in each island system.

Acknowledgments This study incorporates our combined experience on tropical small islands in many parts of the world and would not have been possible without generous financial support from a wide range of agencies. Our current collaboration is supported by the C-Change International Community-University Research Alliance (ICURA) co-funded by the Social Sciences and Humanities Research Council and the International Development Research Centre. Our past work has been supported by the Canadian International Development Agency, the Japan International Cooperation Agency, the South Pacific Applied Geoscience Commission (SOPAC), and the Geological Survey of Canada (GSC) (Natural Resources Canada), among others. We are grateful to Andrea Darlington (University of Victoria and GSC) for assistance with the SLR projections, to Gavin Manson and Paul Fraser (GSC) for advice on mapping issues, to Dick Pickrill (GSC retired) for his unstinting support of our South Pacific collaboration in the 1990s, and not least to our late colleague Steve Solomon (GSC and SOPAC), who applied his singular skills and insight to the study of Arctic coasts and tropical small islands. We are grateful to Vaughn Barrie and John Shaw (both GSC) and two anonymous journal reviewers for helpful comments on an earlier draft. This is a contribution to LOICZ (Land-Ocean Interactions in the Coastal Zone) and is contribution no. 20120460 of the Earth Sciences Sector (Natural Resources Canada). ${ }^{\circ}$ Canadian Crown Copyright reserved 2013.
Open Access This article is distributed under the terms of the Creative Commons Attribution License which permits any use, distribution, and reproduction in any medium, provided the original author(s) and the source are credited.

\section{References}

Adey WH (1978) Coral reef morphogenesis: a multidimensional model. Science 202:831-837

Allen M (1998) Holocene sea-level change on Aitutaki, Cook Islands: landscape change and human response. J Coastal Res 14:10-22

Baines GBK, McLean RF (1976) Sequential studies of hurricane deposit evolution at Funafuti Atoll. Mar Geol 21:M1-M8

Bard E, Hamelin B, Arnold M, Montaggioni L, Cabioch G, Faure G, Rougerie F (1996) Deglacial sea-level record from Tahiti corals and the timing of global meltwater discharge. Nature 382:241-244

Barnett J, Campbell J (2010) Climate change and small island states: power, knowledge and the South Pacific. Earthscan, London

Boudon G, le Friant A, Komorowski JC, Deplus C, Semet MP (2007) Volcano flank instability in the Lesser Antilles Arc: diversity of scale, processes and temporal recurrence. J Geophys Res 112: B08205

Bouysse P, Westercamp D, Andreieff P (1990) The Lesser Antilles island arc. Proc ODP Sci Results 110:29-44

Camoin GF, Colonna M, Montaggioni LF, Casanova J, Faure G, Thomassin BA (1997) Holocene sea level changes and reef development in the southwestern Indian Ocean. Coral Reefs 16:247-259

Carilli JE, Norris RD, Black B, Walsh SM, McField M (2010) Century-scale records of coral growth rates indicate that local stressors reduce coral thermal tolerance threshold. Glob Change Biol 16:1247-1257

Cazenave A, Llovel W (2010) Contemporary sea level rise. Annu Rev Marine Sci 2:145-173

Chappell J (1980) Coral morphology, diversity and reef growth. Nature 286:249-252

Church JA, White NJ (2006) A 20th century acceleration in global sea-level rise. Geophys Res Lett 33:L01602

Church JA, White NJ (2011) Sea-level rise from the late 19th to the early 21st century. Surv Geophys 32:585-602

Church JA, White NJ, Coleman R, Lambeck K, Mitrovica JX (2004) Estimates of the regional distribution of sea level rise over the 1950-2000 period. J Clim 17:2609-2625

Church JA, White NJ, Hunter JR (2006) Sea-level rise at tropical Pacific and Indian Ocean islands. Global Planet Change 53:155-168

Church JA, White NJ, Aarup T, Wilson WS, Woodworth PL, Domingues CM, Hunter JR, Lambeck K (2008) Understanding global sea levels: past, present and future. Sustain Sci 3:9-22

Clift PD, MacLeod CJ, Tappin DR, Wright DJ, Bloomer SH (1998) Tectonic controls on sedimentation and diagenesis in the Tonga Trench and forearc, southwest Pacific. Geol Soc Am Bull 110:483-496

Collier JS, Minshull TA, Kendal JM, Whitmarsh RB, Rumpker G, Joseph P, Samson P, Lane CI, Snasom V, Vermeesch PM, Hammond J, Wookney J, Teanby T, Ryberg TM, Dean SM (2004) Rapid continental breakup and microcontinent formation in the western Indian Ocean. Eos Trans Am Geophys Union 85:481

Crump J, Kelman I (2009) Many strong voices from Arctic to island peoples. In: Climate change and Arctic sustainable development, UNESCO, Paris, pp 284-295 
Darwin C (1842) The structure and distribution of coral reefs. Smith, Elder and Co., London

Davis D, Sutherland M, Jaggam S, Singh D (2012) Determining and monitoring sea level in the Caribbean using satellite altimetry. In: Knowing to manage the territory, protect the environment, evaluate the cultural heritage, FIG working week 2012, Rome, Session TS08D, pp 1-13

de Scally FA (2008) Historical tropical cyclone activity and impacts in the Cook Islands. Pac Sci 62:443-459

Dickinson WR, Burley DV, Shutler R Jr (1999) Holocene paleoshoreline record in Tonga: geomorphic features and archaeological implications. J Coastal Res 15:682-700

Domingues CM, Church JA, White NJ, Gleckler PJ, Wijffels SE, Barker PM, Dunn JR (2008) Improved estimates of upper-ocean warming and multi-decadal sea-level rise. Nature 453:10901093

Donner S (2012) Sea level rise and the ongoing battle of Tarawa. Eos Trans Am Geophys Union 93:169-170

Emery KO (1961) A simple method of measuring beach profiles. Limnol Oceanogr 6:90-93

Emery KO, Milliman JD (1980) Shallow-water limestones from the slope off Grand Cayman Island. J Geol 88:483-488

Forbes DL (1995) Coastal stability and sand transport, Aitutaki, southern Cook Islands. South Pacific Applied Geoscience Commission, Suva, SOPAC technical report 226, http://ict. sopac.org/VirLib/TR0226.pdf. Accessed 11 September 2012

Forbes DL (1996) Coastal geology and hazards of Niue. South Pacific Applied Geoscience Commission, Suva, SOPAC technical report 233, http://ict.sopac.org/VirLib/TR0233.pdf. Accessed 24 September 2012

Forbes DL, Biribo N (1996) Shore-zone sand and gravel of South Tarawa, Kiribati: preliminary assessment of selected sites. South Pacific Applied Geoscience Commission, Suva, SOPAC technical report 235, http://ict.sopac.org/VirLib/TR0235.pdf. Accessed 11 September 2012

Forbes DL, Kruger J, Motuiwaca S, Naibitakele N (1995) Coastal sedimentation and shore processes, Natadola Beach, Viti Levu, Fiji. South Pacific Applied Geoscience Commission, Suva, SOPAC preliminary report 83, http://ict.sopac.org/VirLib/ LR0083.pdf. Accessed 23 September 2012

Fritz HM, Synolakis CE, McAdoo BG, Caputo R (2006) Maldives field survey of the 2004 Indian Ocean tsunami. Earthq Spectra 22: S137-S154. http://faculty.vassar.edu/brmcadoo/EERI_ Maldives_FzSyMcCa3.pdf. Accessed 7 September 2012

Fritz HM, Borrero JC, Synolakis CE, Okal EA, Weiss R, Titov VV, Jaffe BE, Foteinis S, Lynett PJ, Chan I-C, Liu PL-F (2011) Insights on the 2009 South Pacific tsunami in Samoa and Tonga from field surveys and numerical simulations. Earth-Sci Rev 107:66-75

Glaser M, Kremer H, Ramachandran R, Carruthers T, Newton A, Forbes DL, Wolanski E (2012) Addressing five grand challenges for islands at risk. In: Proceedings of planet under pressure conference 2012, London, http://www.loicz.org/imperia/md/ content/loicz/pup/addressing_five_grand_challenges_for_islands_ at_risk.pdf. Accessed 11 September 2012

Gourlay MR (1994) Wave transformation on a coral reef. Coast Eng 23:17-42

Grinsted A, Moore JC, Jevrejeva S (2009) Reconstructing sea level from paleo and projected temperatures 200 to 2100 AD. Clim Dyn 34:461-472

Harbitz CB, Glimsdal S, Bazin S, Zamora N, Løvholt F, Bungum H, Smebye H, Gauer P, Kjekstad O (2012) Tsunami hazard in the Caribbean: regional exposure derived from credible worst case scenarios. Cont Shelf Res 38:1-23

Harp EL, Reid ME, Michael JA (2004) Hazard analysis of landslides triggered by Typhoon Chata'an on July 2, 2002, in Chuuk State,
Federated States of Micronesia. US Geological Survey, open-file report 2004-2348

Harris A, Manahira G, Sheppard A, Gough C, Sheppard C (2010) Demise of Madagascar's once great barrier reef: changes in coral reef conditions over 40 years. Atoll Res Bull 574:1-16

Hay J, Mimura N (2010) The changing nature of extreme weather and climate events: risks to sustainable development. Geomat Nat Hazards Risk 1:3-18

Herrmann TM, Ronneberg E, Brewster M, Dengo M (2004) Social and economic aspects of disaster reduction, vulnerability and risk management in small island developing states. In: Small island habitats, proceedings of United Nations conference on small island states, Mauritius, pp 231-233

Hoegh-Guldberg O, Mumby PJ, Hooten AJ, Steneck RS, Greenfield P, Gomez E, Harvell CD, Sale PF, Edwards AJ, Caldeira K, Knowlton N, Eakin CM, Iglesias-Prieto R, Muthiga N, Bradbury RH, Dubi A, Hatziolos ME (2007) Coral reefs under rapid climate change and ocean acidification. Science 318:1737-1742

Horsfield WT (1975) Quaternary movements in the Greater Antilles. Geol Soc Am Bull 86:933-938

IPCC (2007) Climate change 2007: synthesis report. Core Writing Team, Pachauri RK, Reisinger A (eds) Contribution of working groups I, II and III to the fourth assessment report of the Intergovernmental Panel on Climate Change. IPCC, Geneva

Jackson LE Jr, Barrie JV, Forbes DL, Shaw J, Manson GK, Schmidt M (2005) Effects of the 26 December 2004 Indian Ocean tsunami in the Republic of Seychelles. Geological Survey of Canada, Ottawa, open file 4935, http://www.unisdr.org/files/ 2193_VL323132.pdf. Accessed 24 September 2012

Jacobson G, Hill PJ (1980) Hydrogeology of a raised coral atollNiue Island, south Pacific Ocean. BMR J Aust Geol Geophys 5:271-278

James TS, Simon KM, Forbes DL, Dyke AS, Mate DJ (2011) Sealevel projections for five pilot communities of the Nunavut climate change partnership. Geological Survey of Canada, Ottawa, open file 6715

Jevrejeva S, Grinsted A, Moore JC, Holgate S (2006) Nonlinear trends and multiyear cycles in sea level records. J Geophys Res 111:C09012

Jevrejeva S, Moore JC, Grinsted A, Woodworth PL (2008) Recent global sea level acceleration started over 200 years ago? Geophys Res Lett 35:L08715

Jevrejeva S, Moore JC, Grinsted A (2010) How will sea level respond to changes in natural and anthropogenic forcings by 2100 ? Geophys Res Lett 37:L07703

Jevrejeva S, Moore JC, Grinsted A (2012) Sea level projections to AD2500 with a new generation of climate change scenarios. Global Planet Change 80-81:14-20

Jones B, Hunter IG (1990) Pleistocene paleogeography and sea levels on the Cayman Islands, British West Indies. Coral Reefs 9:81-91

Jones B, Ng K-C, Hunter IG (1997) Geology and hydrogeology of the Cayman Islands. In: Vacher HL, Quinn T (eds) Geology and hydrogeology of carbonate islands. Developments in sedimentology, vol 54, pp 299-326

Kalbfleisch WBC, Jones B (1998) Sedimentology of shallow, hurricane-affected lagoons: Grand Cayman, British West Indies. J Coastal Res 14:140-160

Kelman I, West JJ (2009) Climate change and small island developing states: a critical review. Ecol Environ Anthropol 5:1-16

Kench PS (2012) Compromising reef island shoreline dynamics: legacies of the engineering paradigm in the Maldives. In: Cooper JAG, Pilkey $\mathrm{OH}$ (eds) Pitfalls of shoreline stabilization: selected case studies. Springer, Dordrecht. Coastal Research Library, vol 3, pp 165-186

Kench PS, Cowell PJ (2001) The morphological response of atoll islands to sea-level rise: part 2: application of the modified shoreface translation model (STM). J Coast Res SI 34:645-656 
Kench PS, McLean RF, Nichol SL (2005) New model of reef-island evolution: Maldives, Indian Ocean. Geology 33:145-148

Kench PS, McLean RF, Brander RW, Nichol SL, Smithers SG, Ford MR, Parnell KE, Aslam M (2006) Geological effects of tsunami on mid-ocean atoll islands: the Maldives before and after the Sumatran tsunami. Geology 34:177-180

Kostaschuk R, Terry J, Raj R (2001) Tropical cyclones and floods in Fiji. Hydrol Sci J 46:435-450

Krastel S, Schmincke HU, Jacobs CL, Rihm R, Le Bas TM, Alibés B (2001) Submarine landslides around the Canary Islands. J Geophys Res 106(B3): 3977-3997

Lata S, Nunn P (2011) Misperceptions of climate-change risk as barriers to climate-change adaptation: a case study from the Rewa Delta, Fiji. Clim Change 110:169-186

Le Friant A, Boudon G, Komorowski JC, Heinrich P, Semet MP (2006) Potential flank-collapse of Soufriere volcano, Guadeloupe, Lesser Antilles? Nat Hazards 39:381-393

Le Friant A, Boudon G, Arnulf A, Robertson REA (2009) Debris avalanche deposits offshore St. Vincent (West Indies): impact of flank-collapse events on the morphological evolution of the island. J Volcanol Geoth Res 179:1-10

Leuliette EW, Nerem RS, Mitchum GT (2004) Calibration of TOPEX/Poseidon and Jason altimeter data to construct a continuous record of mean sea level change. Mar Geodesy 27:79-94

Louvat P, Allègre CJ (1997) Present denudation rates on the island of Réunion determined by river geochemistry: basalt weathering and mass budget between chemical and mechanical erosion. Geochim Cosmochim Acta 61:3645-3669

Maragos JE, Baines GBK, Beveridge PJ (1973) Tropical Cyclone Bebe creates new land formation on Funafuti Atoll. Science 181:1161-1164

Massel SR, Gourlay MR (2000) On the modelling of wave breaking and set-up on coral reefs. Coast Eng 39:1-27

McAdoo BG, Moore A, Baumwell J (2009) Indigenous knowledge and the near field population response during the 2007 Solomon Islands tsunami. Nat Hazards 48:73-82

McClanahan T, Polunin N, Done T (2002) Ecological states and the resilience of coral reefs. Conserv Ecol 6(2):18. http://www.consecol.org/vol6/iss2/art18. Accessed 11 September 2012

McKee ED (1959) Storm sediments on a Pacific atoll. J Sediment Petrol 29:354-364

McLean RF, Woodroffe CD (1994) Coral atolls. In: Carter RWG, Woodroffe CD (eds) Coastal evolution: Late Quaternary shoreline morphodynamics. Cambridge University Press, Cambridge, pp 267-302

Meehl GA, Stocker TF, Collins WD, Friedlingstein P, Gaye AT, Gregory JM, Kitoh R, Knutti R, Murphy JM, Noda A, Raper SCB, Watterson IG, Weaver AJ, Zhao Z-C (2007) Global climate projections. In: Solomon S, Qin D, Manning M, Chen Z, Marquis M, Averyt KB, Tignor M, Miller HL (eds) Climate change 2007: the physical science basis. Contribution of working group I to the fourth assessment report of the Intergovernmental Panel on Climate Change. Cambridge University Press, Cambridge, pp 747-846

Mercer J, Kelman I, Suchet-Pearson S, Lloyd L (2009) Integrating indigenous and scientific knowledge bases for disaster-risk reduction in Papua New Guinea. Geogr Ann 91B:157-183

Mimura N, Nunn PD (1998) Trends of beach erosion and shoreline protection in rural Fiji. J Coastal Res 14:37-46

Mimura N, Nurse L, McLean R, Agard J, Briguglio L, Lefale P, Payet R, Sem G (2007) Small islands. In: Parry ML, Canziani OF, Palutikof JP, van der Linden PJ, Hanson CE (eds) Climate change 2007: impacts, adaptation and vulnerability. Contribution of working group II to the fourth assessment report of the
Intergovernmental Panel on Climate Change. Cambridge University Press, Cambridge, pp 687-716

Mitrovica JX, Tamisiea ME, Davis JL, Milne GA (2001) Recent mass balance of polar ice sheets inferred from patterns of global sealevel change. Nature 409:1026-1029

Morton RA, Richmond BM, Jaffe BE, Gelfenbaum G (2006) Reconnaissance investigation of Caribbean extreme wave deposits-preliminary observations, interpretations, and research directions. US Geological Survey, open-file 2006-1293

Nakicenovic N, Swart R (eds) (2000) Special report on emission scenarios: a special report of working group III, Intergovernmental Panel on Climate Change. Cambridge University Press, New York

Nash MC, Opdyke BN, Troitzsch U, Russell BD, Adey WH, Kato A, Diaz-Pulido G, Brent C, Gardner M, Prichard J, Kline DI (2013) Dolomite-rich coralline algae in reefs resist dissolution in acidified conditions. Nat Clim Change 3:268-272

Neumann AC, Macintyre IG (1985) Reef response to sea level rise: keep-up, catch-up or give-up. In: Proceedings of the 5th international coral reef congress, vol 3, pp 105-110

Nicholls RJ, Woodroffe CD, Burkett V, Hay J, Wong PP, Nurse L (2012) Scenarios for coastal vulnerability assessment. In: Wolanski E, McLusky DS (eds) Treatise on estuarine and coastal science, vol 12. Academic, Waltham, pp 289-303

Nichols S, Tienaah T, Forbes D, Sutherland M (2011) Mobilizing local knowledge to bridge information gaps in climate change adaptation planning. In: People in places: engaging together in integrated resource management, Halifax, June 2011. http://www. coastalcura.ca/documents/NicholsSecured.pdf. Accessed 26 September 2012

Nunn PD (1994) Oceanic islands. Blackwell, Oxford

Nunn PD, Veitayaki J, Ram-Bidesi V, Vunisea A (1999) Coastal issues for oceanic islands: implications for human futures. Nat Resour Forum 23:195-207

O'Loughlin KF, Lander JF (2003) Caribbean tsunamis, a 500-year history from 1498-1998, 2nd edn. Springer, Dordrecht

Oehler J-P, Lénat J-F, Labazuy P (2008) Growth and collapse of the Reunion Island volcanoes. Bull Volcanol 70:717-742

Ostrom E (1999) Coping with tragedies of the commons. Annu Rev Polit Sci 2:493-535

Ostrom E (2010) A long polycentric journey. Annu Rev Polit Sci 13:1-23

Pelling M, Uitto JI (2001) Small island developing states: natural disaster vulnerability and global change. Environ Hazards 3:49-62

Perfit MR, Heezen BC (1978) The geology and evolution of the Cayman Trench. Geol Soc Am Bull 89:1155-1174

Perry CT, Spencer T, Kench PS (2008) Carbonate budgets and reef production states: a geomorphic perspective on the ecological phase-shift concept. Coral Reefs 27:853-866

Perry CT, Kench PS, Smithers SG, Riegl B, Yamano H, O’Leary MJ (2011) Implications of reef ecosystem change for the stability and maintenance of coral reef islands. Glob Change Biol 17:3679-3696

Perry CT, Smithers SG, Gulliver P, Browne NK (2012) Evidence of very rapid reef accretion and reef growth under high turbidity and terrigenous sedimentation. Geology 40:719-722

Perry CT, Murphy GN, Kench PS, Smithers SG, Edinger EN, Steneck RS, Mumby PJ (2013) Caribbean-wide decline in carbonate production threatens coral reef growth. Nat Commun 4:1402

Pfeffer WT, Harper JT, O'Neel S (2008) Kinematic constraints on glacier contributions to 21 st century sea-level rise. Science 321:1340-1343

Pirazzoli PA, Montaggioni LF, Salvat B, Faure G (1988) Late Holocene sea level indicators from twelve atolls in the central and eastern Tuamotus (Pacific Ocean). Coral Reefs 7:57-68 
Rahmstorf S (2007) A semi-empirical approach to projecting future sea-level rise. Science 315:368-370

Rahmstorf S (2010) A new view on sea level rise. Nat Rep Clim Change 4:44-45

Rahmstorf S (2012) Sea-level rise: towards understanding local vulnerability. Environ Res Lett 7:021001

Rahmstorf S, Cazenave A, Church JA, Hansen JE, Keeling RF, Parker DE, Somerville RCJ (2007) Recent climate observations compared to projections. Science 316:709

Rahmstorf S, Foster G, Casenave A (2012a) Comparing climate projections to observations up to 2011. Environ Res Lett 7:044035

Rahmstorf S, Perrette M, Vermeer M (2012b) Testing the robustness of semi-empirical sea level projections. Clim Dyn 39:861-875

Richmond BM (1992) Development of atoll islets in the central Pacific. In: Proceedings of the 7th international coral reef congress, vol 2, pp 1185-1194

Scheffers A (2005) Coastal response to extreme wave eventshurricanes and tsunami on Bonaire. Essener Geographische Arbeiten 37:1-100

Schwerdtner Máñez K, Husain S, Ferse SCA, Máñez Costa M (2012) Water scarcity in the Spermonde Archipelago, Sulawesi, Indonesia: past, present and future. Environ Sci Policy 23:74-84

Scoffin TP (1993) The geological effects of hurricanes on coral reefs and the interpretation of storm deposits. Coral Reefs 12:203-221

Scott CAJ, Rotondo GM (1983) A model to explain the differences between Pacific plate island atoll types. Coral Reefs 1:139-150

Shaw J, Jackson LE Jr, Forbes DL, Barrie JV, Manson GK, Schmidt M (2005) Tsunami impacts in the Republic of Seychelles following the great Sumatra earthquake of 26 December 2004. In: Proceedings of Canadian coastal conference 2005, Dartmouth, NS. Canadian Coastal Science and Engineering Association, Ottawa, pp 1-20

Sheppard C, Dixon DJ, Gourlay M, Sheppard A, Payet R (2005) Coral mortality increases wave energy reaching shores protected by reef flats: examples from the Seychelles. Estuar Coast Shelf Sci 64:223-234

Smith SV, Buddemeier RW (1992) Global change and coral reef ecosystems. Annu Rev Ecol Syst 23:89-118

Solomon SM (1997) Circulation studies in Manihiki Lagoon, Cook Islands. South Pacific Applied Geoscience Commission, Suva, SOPAC technical report 246, http://ict.sopac.org/VirLib/TR0246. pdf. Accessed 24 September 2012
Solomon SM, Forbes DL (1999) Coastal hazards and associated management issues on South Pacific islands. Ocean Coast Manag 42:523-554

Stoddart DR (1975) Scientific studies in the southern Cook Islands: background and bibliography. In: Stoddart DR, Gibbs PE (eds) Almost-atoll of Aitutaki: reef studies in the Cook Islands, South Pacific. Atoll Res Bull 190:1-30

Sutherland M, Dare P, Miller K (2008) Monitoring sea-level change in the Caribbean. Geomatica 62:428-436

Teeuw R, Rust D, Solana C, Dewdney C (2009) Large coastal landslides and tsunami hazard in the Caribbean. Eos Trans Am Geophys Union 90:81-82

Tienaah T (2011) Design and implementation of a coastal collaborative GIS to support sea level rise and storm surge adaptation strategies. M. Sc. E. thesis, Department of Geodesy and Geomatics Engineering, University of New Brunswick, Fredericton, technical report 276

Webb AP, Kench PS (2010) The dynamic response of reef islands to sea-level rise: evidence from multi-decadal analysis of island change in the central Pacific. Glob Planet Change 72:234-246

Woodroffe CD (2002) Coasts: form, process and evolution. Cambridge University Press, Cambridge

Woodroffe CD (2008) Reef-island topography and the vulnerability of atolls to sea-level rise. Glob Planet Change 62:77-96

Woodroffe CD, McLean RF, Smithers SG, Lawson EM (1999) Atoll reef-island formation and response to sea-level change: West Island, Cocos (Keeling) Islands. Mar Geol 160:85-104

Woodroffe CD, Samosorn B, Hua Q, Hart DE (2007) Incremental accretion of a sandy reef island over the past 3000 years indicated by component-specific radiocarbon dating. Geophys Res Lett 34:L03602

Woodworth PL, Player R (2003) The Permanent Service for Mean Sea Level: an update to the 21st century. J Coastal Res 19:287-295

Yamano H, Kayanne H, Chikamori M (2005) An overview of the nature and dynamics of reef islands. Glob Environ Res 9:9-20

Yamano H, Kayanne H, Yamaguchi T, Kuwahara Y, Yokoki H, Shimazaki H, Chikamori M (2007) Atoll island vulnerability to flooding and inundation revealed by historical reconstruction: Fongafale Islet, Funafuti Atoll, Tuvalu. Glob Planet Change 57:407-416

Zachariasen J, Sieh K, Taylor FW, Edwards RL, Hantoro WS (1999) Submergence and uplift associated with the giant 1833 Sumatran subduction earthquake: evidence from coral microatolls. J Geophys Res 104:895-919 